10-2002

\title{
The Varieties of Knowledge and Skill-Based Pay Design: A Comparison of Seven New Pay Systems for K-12 Teachers
}

Anthony Milanowski

Follow this and additional works at: https://repository.upenn.edu/cpre_researchreports

Part of the Curriculum and Instruction Commons, and the Teacher Education and Professional Development Commons

\section{Recommended Citation}

Milanowski, Anthony. (2002). The Varieties of Knowledge and Skill-Based Pay Design: A Comparison of Seven New Pay Systems for K-12 Teachers. CPRE Research Reports.

Retrieved from https://repository.upenn.edu/cpre_researchreports/29

View on the CPRE website.

This paper is posted at ScholarlyCommons. https://repository.upenn.edu/cpre_researchreports/29

For more information, please contact repository@pobox.upenn.edu. 


\title{
The Varieties of Knowledge and Skill-Based Pay Design: A Comparison of Seven New Pay Systems for K-12 Teachers
}

\author{
Abstract \\ A number of lines of research (e.g., National Commission on Teaching and America's Future, 1996; Slavin \\ \& Fashola, 1998; Wright, Horn, \& Sanders, 1997; Bembry, Jordan, Gomez, Anderson, \& Mendro, 1998; \\ Ferguson \& Ladd, 1996) have identified teacher instructional capacity as a key variable in the success of \\ educational reforms in improving student achievement. Since 2000, the Consortium for Policy Research \\ in Education has been studying a new form of teacher compensation that may have the potential to \\ support improvements in the capacity of teachers to deliver instruction that would enable all children to \\ achieve to high academic standards, as well as to respond to the growing public concern that there be \\ some link between teacher salaries and teacher performance. This innovation -- knowledge and skill- \\ based pay -- rewards teachers with base pay increases and/or bonuses for acquiring and demonstrating \\ specific knowledge and skills needed to meet educational goals, such as improving student achievement. \\ The application of this pay concept to K-12 education has been suggested by Conley and Odden (1995), \\ Mohrman, Morhman, and Odden (1996), and Odden and Kelley (1997). This report examines a study of \\ seven knowledge and skill-based pay systems for teachers that have been developed by U.S. schools or \\ districts.

\section{Disciplines} \\ Curriculum and Instruction | Teacher Education and Professional Development
}

\section{Comments}

View on the CPRE website. 


\title{
The Varieties of Knowledge and Skill-based Pay Design: A Comparison of Seven New Pay Systems for K-12 Teachers
}

\author{
Anthony Milanowski \\ CPRE Research Report Series \\ RR-050 \\ October 2002 \\ Consortium for Policy Research in Education \\ University of Pennsylvania \\ Graduate School of Education
}





\section{Contents}

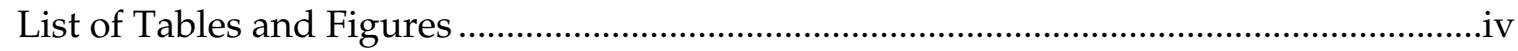

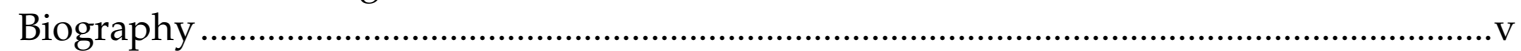

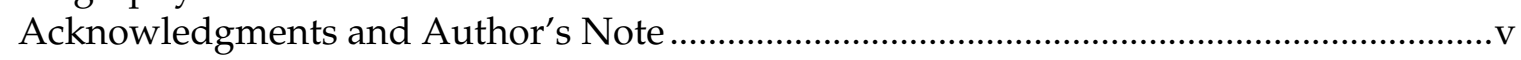

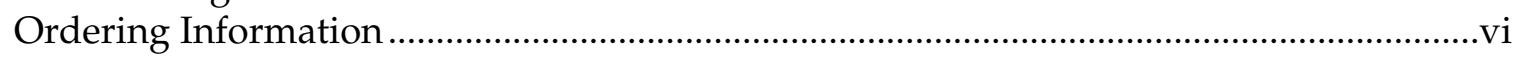

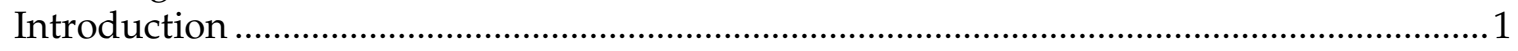

The Theory of Action for Knowledge and Skill-based Pay …............................................... 2

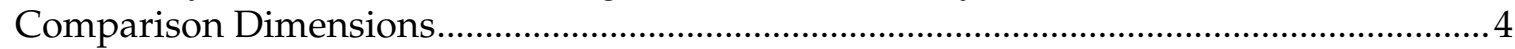

Impetus or Motivation for Developing the Knowledge and Skill-based Pay Program .. 4

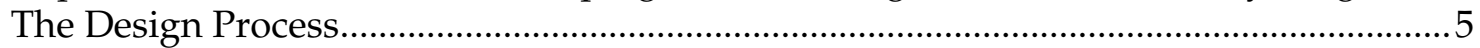

Types and Structure of Knowledge and Skills Rewarded .............................................. 6

How Knowledge and Skill Acquisition is Assessed.................................................... 6

The Size and Structure of the Knowledge and Skill Incentives ....................................... 7

Alignment of Other Human Resource Programs in Support of the Knowledge and

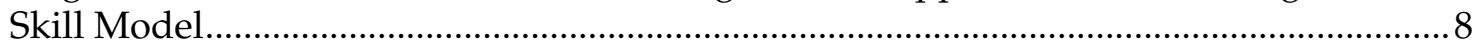

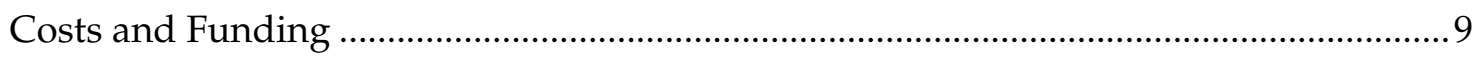

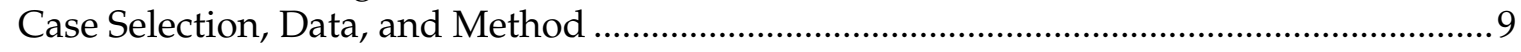

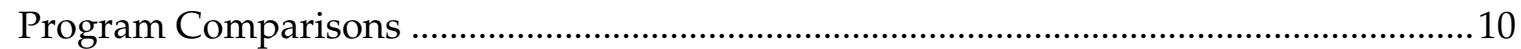

Motivation for Developing the Knowledge and Skill-based Pay Program.................... 10

Process Used to Design the Program................................................................................ 12

Knowledge and Skills Rewarded and their Organization into a Structure ....................15

How Knowledge and Skill Acquisition was Assessed...................................................17

Size and Structure of Knowledge and Skill Incentives ...................................................19

How the Acquisition of the Knowledge and Skills are Supported ..................................22

Additional Costs of the Programs and Methods of Funding ..........................................24

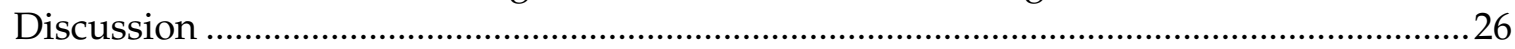

Implications for Research on Knowledge and Skill-based Pay in the K-12 Sector ........28

Implications for Policymakers and Program Designers ...............................................29

References ......................................................................................................................... 31

Appendix A. Brief Descriptions of the Seven Knowledge and Skill-based Pay (KSBP)

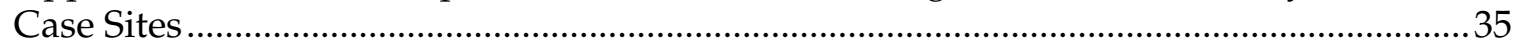

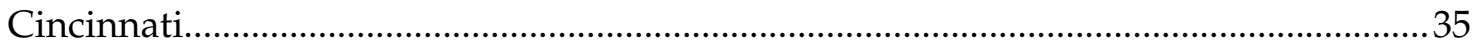

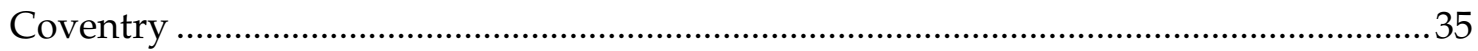

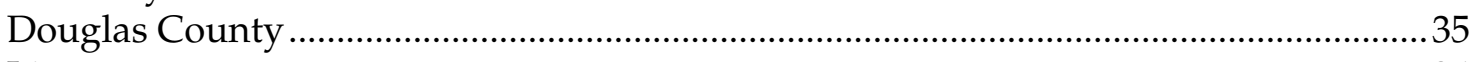

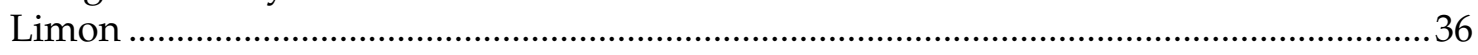

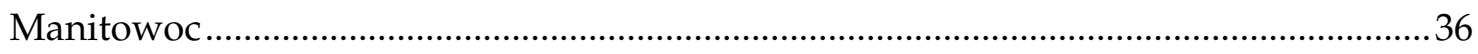

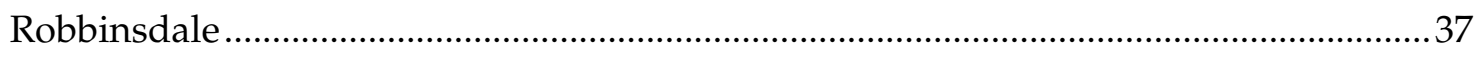

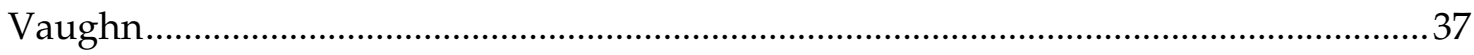




\section{List of Tables and Figures}

Table 1. Initiation of Knowledge and Skill-based Pay (KSBP) Design Process...................11

Table 2. Characteristics of Knowledge and Skill-based Pay Design Process...................... 13

Table 3. Knowledge and Skills Rewarded: Content and Structure .....................................16

Table 4. Methods of Assessment....................................................................................... 18

Table 5. Knowledge and Skill Pay Provisions and Relative Size of Incentive.................... 20

Table 6. Integration with Professional Development and Other Human Resource

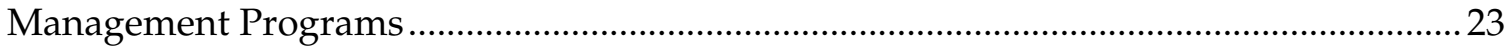

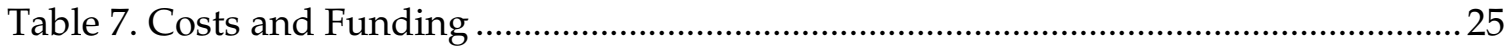

Figure 1. Theory of Action for Knowledge and Skill-based Pay ..........................................

Figure 2. Motivational Model for Knowledge and Skill-based Pay Based on Expectancy

Theory..... 


\section{Biography}

Anthony Milanowski is a researcher with the Consortium for Policy Research in Education (CPRE) at the University of Wisconsin-Madison. He has also taught courses in compensation, staffing, and general human resource management at the University of Wisconsin-Madison's School of Business.

\section{Acknowledgments and Author's Note}

This report is based on research conducted by CPRE. CPRE is sponsored by the National Institute on Educational Governance, Finance, Policymaking, and Management; Office of Educational Research and Improvement; U.S. Department of Education (OERI Grant No. R308A960003). Opinions expressed in this publication are those of the author and do not necessarily reflect the views of the National Institute on Educational Governance, Finance, Policymaking, and Management; the Office of Educational Research and Improvement; the U.S. Department of Education; the Wisconsin Center for Education Research; CPRE; or its institutional members.

This report is primarily based on case studies done by staff researchers with CPRE's teacher compensation project at the University of Wisconsin-Madison. The original authors of the cases studies are: Eric Conti (Limon, CO; Robbinsdale, MN; and Coventry, RI); Eric Conti, with the assistance of Eileen Kellor (Manitowoc, WI); Carolyn Kelley (Douglas County, CO); Eileen Kellor (Vaughn Next Century Learning Center, Los Angeles, CA); and Eileen Kellor and Allan Odden (Cincinnati, $\mathrm{OH}$ ). These cases are available at www.wcer.wisc.edu/cpre.

The author wishes to thank these researchers for allowing him to use their work, and to assure them and the reader that any errors in the descriptions, analysis, or conclusions in this report are his responsibility.

Finally, the reader should be aware that staff of CPRE's University of WisconsinMadison office were involved in the development of two of these programs. Allan Odden and Eileen Kellor provided consultation and technical assistance to the district committee that designed the Cincinnati program, and Odden continues to provide consultation to the district. Anthony Milanowski and Kellor have been involved in evaluations of the program paid for by the district. Odden has provided technical assistance to staff at the Vaughn Next Century Learning Center, and Milanowski has provided occasional advice to Vaughn in the course of exploratory research on that school's program. Though the author does not believe that this involvement has biased his description or implicit evaluation of the programs discussed here, the reader may want to remember this involvement when reading this report. 


\section{Ordering Information}

Copies of this report are available for $\$ 5.00$ each. Prices include book-rate postage and handling. Make checks payable to Trustees of the University of Pennsylvania. Sorry, we cannot accept returns, credit card orders, or purchase orders. Sales tax is not applicable. To obtain copies, write:

CPRE Publications

Graduate School of Education

University of Pennsylvania

3440 Market Street, Suite 560

Philadelphia, PA 19104-3325

Quantity discounts are available. For more information, please call (215) 573-0700. 


\section{Introduction}

A number of lines of research (e.g., National Commission on Teaching and America's Future, 1996; Slavin \& Fashola, 1998; Wright, Horn, \& Sanders, 1997; Bembry, Jordan, Gomez, Anderson, \& Mendro, 1998; Ferguson \& Ladd, 1996) have identified teacher instructional capacity as a key variable in the success of educational reforms in improving student achievement. For the past two years, the Consortium for Policy Research in Education has been studying a new form of teacher compensation that may have the potential to support improvements in the capacity of teachers to deliver instruction that would enable all children to achieve to high academic standards, as well as to respond to the growing public concern that there be some link between teacher salaries and teacher performance. This innovation - knowledge and skillbased pay - rewards teachers with base pay increases and/or bonuses for acquiring and demonstrating specific knowledge and skills needed to meet educational goals, such as improving student achievement. The application of this pay concept to K-12 education has been suggested by Conley and Odden (1995), Mohrman, Morhman, and Odden (1996), and Odden and Kelley (1997). This report examines a study of seven knowledge and skill-based pay systems for teachers that have been developed by U.S. schools or districts.

Knowledge and skill-based pay can be better understood by contrasting it with two other teacher pay systems. Unlike the traditional single salary schedule, on which teachers progress through the salary schedule based on the number of years of service and the additional degrees or college credits they acquire, knowledge and skill-based systems provide pay increases when teachers demonstrate, usually through some form of performance assessment, that they have acquired and can apply classroomrelevant knowledge and skills. Ideally, pay progression is based on mastering a sequence of knowledge and skills that represent higher levels of expertise or higher levels of teaching practice. The intent of knowledge and skill-based pay is to supplement or replace the traditional schedule with a pay system that motivates teachers to acquire and demonstrate the application of knowledge and skills that more directly contribute to better school performance and student achievement. The importance of seniority as a basis for pay is reduced or even eliminated.

The other contrast is with merit pay programs. Merit pay typically involves providing individual teachers with base pay increases by allotting a fixed fund of money based on administrators' subjective judgments of teacher performance during the prior year. While knowledge and skill-based pay programs also reward individual teachers, the reward is based on demonstrating knowledge and skills with respect to public, relatively detailed standards or descriptions of practice. These standards both guide assessor judgments and make known to teachers "up front" what they need to do to demonstrate the knowledge and skills. Since any teacher who demonstrates the skills receives the reward, teachers do not compete for a share of a fixed fund or merit pay pool. These features of knowledge and skillbased pay may make it more effective in motivating teachers than merit pay.

Because knowledge and skill-based pay programs are new and quite rare in the $\mathrm{K}-12$ sector, it is not yet possible to obtain definitive evidence about the success of these programs in influencing 
instructional capacity or in improving student achievement. It is not known whether they are effective in achieving their aims, nor do we yet know all of the difficulties and unintended consequences they may have. So it is too early to tell if they are better or worse than the traditional pay system. This report therefore concentrates on describing and comparing seven pioneer knowledge and skill-based pay programs. To do so, a set of dimensions were derived from an explicit theory of action which links knowledge and skill-based pay to improvements in instructional capacity and student achievement, and from the literature on knowledge and skill-based pay in the private sector.

\section{The Theory of Action for Knowledge and Skill- based Pay}

Knowledge and skill-based pay systems might positively impact instructional capacity, and in turn student achievement, in three ways. First, they provide incentives for teachers to develop specific knowledge and skills needed to increase instructional capacity. More highly-skilled teachers, in turn, are able to deliver higher-quality instruction, which, when combined with motivation to improve instruction and a context conducive to applying the skills, should lead to improved instruction. Second, by allocating higher pay to teachers who have these skills, these programs should help attract and retain high-capacity teachers, and by denying higher pay to teachers without the skills, discourage lower-capacity teachers from staying. Over time, the average skill level of a faculty should increase, improving the average quality of instruction. Third, a well-developed knowledge and skillbased pay system rests on a model of competence that can also be used in teacher evaluation, professional development, and even recruitment and selection. To the extent this model informs these human resource management functions, the organization communicates and reinforces a normative vision of quality instruction. This model can also be used by teachers as a guide to professional development activities, a framework for self-reflection and selfevaluation, and a vocabulary for the discussion of teaching practice. Over time, a shared conception of quality instruction should develop that supports teacher skill-seeking and efforts to improve practice. This in turn contributes to improved student achievement. Figure 1 summarizes this "theory of action" for knowledge and skill-based pay.

The most important process by which knowledge and skill-based pay is expected to function to improve instructional capacity is by providing a pay incentive for knowledge and skill acquisition. However, simply offering teachers a pay increase or bonus will not necessarily motivate them to acquire the needed skills. We have used a modified version of Expectancy Theory (Vroom, 1964) to develop a model to identify what a knowledge and skill-based pay program needs to do in order to motivate skill acquisition (see Figure 2).

This model suggests that in order for knowledge and skill-based pay to motivate effort toward skill acquisition, teachers must first believe that it is likely that if they put forth the effort, they can actually acquire the specified knowledge and skills. This is called the expectancy perception, and is symbolized by the arrow running from effort to knowledge and skill acquisition in Figure 2. This perception is influenced by several 
Figure 1. Theory of Action for Knowledge and Skill-based Pay

Motivation

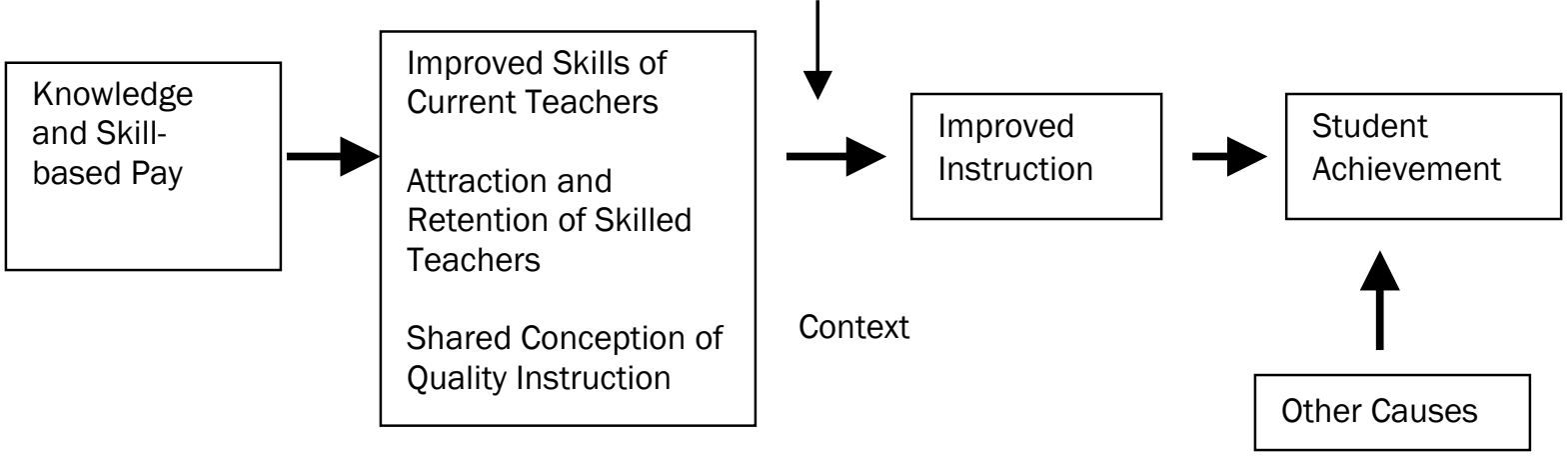

Figure 2. Motivational Model for Knowledge and Skill-based Pay Based on Expectancy Theory

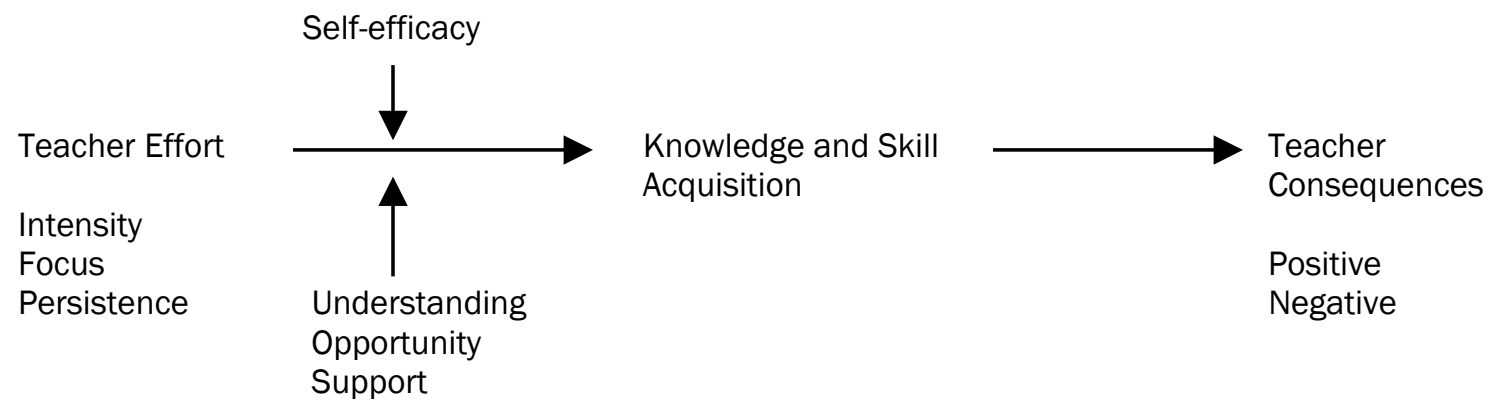

factors, including the teacher's sense of self-efficacy for acquiring the skills and conditions the organization can more easily influence, including the degree to which the teacher understands what knowledge and skills are required and how they are to be demonstrated, the perceived degree of peer and administrator support for developing the skills, and the perceived availability of opportunities to develop the skills (such as high-quality professional development). To the extent that teachers understand the skill requirements, believe that peers and administrators support their acquisition, and believe there are the required opportunities to develop the skills available, they will be more likely to believe that if they try, they will be able to acquire the skills.

Teachers must also believe that there is a strong connection between acquiring the skills and positive consequences such as receiving the pay increase. This link is called the instrumentality perception, and it reflects the common-sense idea that if teachers do not believe that the reward is contingent on acquiring the skills, then the promised reward won't motivate skill-seeking. This link is represented by the arrow from knowledge and skill acquisition to consequences in Figure 2. In order for this perception to be strong, teachers must believe that the promised pay increases will be provided when the 
skills are demonstrated, and will not be provided when they are not. One set of conditions likely to support this belief include a reliable source of funding for the pay increases and the past performance of the organization in keeping promises to teachers. Another condition is that the methods used to assess knowledge and skill acquisition be fair, valid, and reliable. If teachers believe that favoritism or measurement error determines how well one does on the assessment, rather than their true skill level, they will be less likely to expend effort to acquire the skills. If skill acquisition cannot be validly measured, pay increases will be less contingent on skill acquisition, and when teachers realize this, they will be less motivated to acquire the skills.

Acquiring and demonstrating the skills must also have consequences that teachers value. While it is safe to assume teachers value pay increases, these rewards also must be large enough in order to be perceived as worth the effort expended to acquire the specified skills. These rewards will also be more motivating if the knowledge and skill model on which the program is based is accepted by teachers as consistent with their conceptions of quality instruction and a highly-skilled teacher. Presumably, most teachers want to consider themselves good at what they do and are interested in developing their skills toward their ideal of a highly-skilled teacher. They may find this process of development intrinsically rewarding. If the knowledge and skill model is contrary to this ideal, teachers are presented with a choice: develop different skills and get more pay, or develop skills consistent with the ideal and forgo the extra pay. The extrinsic and intrinsic rewards work against each other. It is likely that the extrinsic pay reward will have a more motivating effect if it is consistent with the intrinsic reward. This means that the knowledge and skill model needs to be consistent with teachers' beliefs about what constitutes a highly-skilled teacher. Finally, teachers may also value avoiding certain negative consequences, such as not being recognized as highly skilled or expert. Avoiding these may also be motivating, especially if the definition of "expert" is shared by school-level peers.

\section{Comparison Dimensions}

Based on the theory of action, the motivational model, and the research and practitioner literature on private sector knowledge and skill-based pay systems, seven dimensions were developed to structure the analysis and comparison of the seven cases of knowledge and skillbased pay we studied.

\section{Impetus or Motivation for Developing the Knowledge and Skill-based Pay Program}

The theory of action assumes that policymakers choose to initiate these programs in order to improve instruction and in turn to improve student achievement. Alternatively, adoption of new forms of teacher compensation by pioneer organizations may be motivated by the desire to appear innovative or by the desire of influential decision-makers to implement strongly-held ideas about which teachers should be paid more. In addition, a pay system change can present an opportunity to further other agendas, such as providing additional pay for all teachers or assuring the public that teacher pay is related to teacher performance. The motivation for moving to knowledge and skill-based pay is important because it is likely to be related to design features such as the knowledge 
and skills in the model and the extent to which the new pay structure departs from the traditional salary schedule. One might expect that where the primary motivation is to improve student achievement, the knowledge and skill model will focus on instruction, and pay increases for developing instructional skills will be greater.

\section{The Design Process}

The motivation model suggests that teachers' views of the fairness of various aspects of the program and their acceptance of the model of good teaching implied by the knowledge and skills rewarded will influence their motivation to acquire the knowledge and skills. One way to promote the perceived fairness and acceptability of the system is to have teachers participate in its design. The private sector prescriptive literature on compensation program design (e.g., Lawler, 2000; Ledford, 1991) has advocated such employee participation, as did Odden and Kelley (1997) for education. Participation is thought to increase the level of information employees have about the program's rationale and operation. Employees also have important information to share about what they value, how the program is likely to work in practice, and how they are likely to react to it. Participation is also thought to increase "buy-in." Because a high level of participation is likely to result in greater acceptability and perceived fairness, an important facet of this dimension is the degree to which teachers participated in the design of the program.

One form of teacher participation is through collective bargaining. However, it may be difficult to design a knowledge and skill-based pay program through the standard adversarial collective bargaining process of proposal and counter-proposal, with each side seeking maximum advantage. Knowledge and skill-based pay programs require a coherent design based on some agreed-upon conception of good teaching. Many technical details, such as how knowledge and skills will be assessed, need to be addressed. So it is expected that these programs would be designed either outside the formal contract negotiation process or through an interest-based process (Fisher \& Ury, 1981) that focuses the parties' attention on mutual goals.

Another important aspect of the design process is how program designers decide what knowledge and skills to reward. Designers in the private sector appear to have used inductive, deductive, or adaptive approaches. The inductive approach involves using job analysis or relying on research to identify those knowledge and skills likely to contribute to employee performance. One version of this method is to study known good and average performers to find out what knowledge and skills differ between these groups (Spencer \& Spencer, 1993; American Compensation Association, 1996). The deductive approach involves starting from the organization's strategy, then trying to identify the knowledge and skill employees need to carry it out (Heneman \& Thomas, 1997; American Compensation Association, 1996). The adaptive approach involves starting with a knowledge and skill model developed elsewhere, then changing it to fit local goals and conditions. Though the use of the adaptive method in the private sector has been criticized because it does not provide a unique source of competitive advantage (Ledford \& Heneman, 2000; Zingheim, Ledford, \& Schuster, 1996), it avoids "reinventing the wheel," especially for those core knowledge and 
skills likely to be common across organizations.

In the K-12 sector, the core technology of instruction is likely to be similar across schools. Since there is currently little competition among schools, there is little incentive for very different specifications of knowledge and skills to be identified. There are also economies of effort to be realized by adapting work already done by recognized bodies of experts, such as the standards proposed by the Interstate New Teacher Assessment and Support Consortium (1992), state teacher licensing standards, the National Board for Professional Teaching Standards (NBPTS) standards (1999), or Danielson's Framework for Teaching (Danielson, 1996). Thus, we might expect that many of these pioneer knowledge and skillbased pay programs would have adapted external standards, perhaps adding locally-important skills or modifying language to fit local conditions, rather than attempting to develop an organization-specific model. This approach also allows program designers to appeal to the authority of these external experts when seeking support from teachers and the community.

\section{Types and Structure of Knowledge and Skills Rewarded}

At the heart of a knowledge and skillbased pay program is the specification of the knowledge and skills teachers will be rewarded for developing. The theory of action assumes that the knowledge and skills specified will be those teachers need to deliver instruction that contributes directly to student achievement. Thus, an important facet of this dimension is the degree to which the knowledge and skills rewarded are related to instruction.
Another important facet is the extent to which the knowledge and skills rewarded are organized into an integrated model with a defined continuum of skills or expertise. Knowledge and skill-based pay programs in the private sector often structure the knowledge and skills rewarded into a set of career levels (Jones, 1995; Daniels, 1997), levels defined by rating scales (Heneman \& Thomas, 1997; Gorsline, 1996; American Compensation Association, 1996), or sequences of skills to be mastered (Gupta, Jenkins, \& Curlington, 1986; Jenkins, Ledford, Gupta, \& Doty, 1992). Odden (2000) and Odden and Kelley (1997) sketched a number of different structures of knowledge and skills representing a progression from entry level to accomplished teaching. Such a structure could provide a roadmap for teachers seeking to develop their knowledge and skills as well as convenient attachment points for pay increases. It could also be used to align other parts of the human resource management system, especially professional development programs, and as a guide for teachers working to develop mastery of quality instruction.

\section{How Knowledge and Skill Acquisition is Assessed}

The motivational model suggests that knowledge and skills should be assessed in a way that teachers see as fair and valid, and the theory of action implies that the assessment method must ensure teachers can apply the skills in practice. The traditional degrees and credits seem to be viewed as fair by teachers, but they may not have high validity as indicators of whether skills can be applied in the classroom. Properly constructed and administered, performance-based assessments, which function as samples 
of teachers' instruction, have the potential to ensure that the skills can be applied and to be perceived as valid and fair due to their close connection with practice. Thus, one facet of this dimension is the extent to which performance-based assessments are used, rather than degrees and credits, to provide evidence of knowledge and skill acquisition.

While private sector knowledge and skill-based pay programs typically appear to depend on relatively simple, locallydeveloped assessments (Heneman \& Ledford, 1998), program designers in the $\mathrm{K}-12$ sector have the option of using externally-developed assessments, such as PRAXIS III (Dwyer, 1998), the Framework for Teaching (Danielson, 1996), or the NBPTS assessments. Thirtyone states and more than 200 districts provide some salary incentive for certification (NBPTS, 2001). This avoids the expense and effort of developing local assessments for core teacher skills that are likely to be common across districts or schools (Milanowski, Odden, \& Youngs, 1998; Heneman \& Ledford, 1998).

External assessments may also have the potential for greater validity and fairness than assessments developed locally due to the greater expertise and resources of their developers. External assessments could be used in combination with local assessments to maintain the rigor of the system. The teacher performance evaluation literature (e.g., Wise, DarlingHammond, McLaughlin, \& Bernstein, 1984) suggests that local assessors, such as principals, face many incentives to be less than rigorous. If almost all teachers are judged to have the skills, due to leniency of local assessors, the contingency between skill acquisition and receiving the reward the motivational model postulates as necessary is reduced. (The reward won't motivate effort toward skill acquisition if the assessors certify teachers without the skills as eligible for the reward). Odden (2000) outlined a model knowledge and skill-based pay structure that combined the use of external and local assessments. So a second facet of this dimension is the extent to which external and locallydeveloped assessments are used to provide evidence of knowledge and skill acquisition.

\section{The Size and Structure of the Knowledge and Skill Incentives}

The theory of action proposes that the extra pay offered will motivate teachers to acquire the knowledge and skills needed to improve instruction. To motivate, the pay incentive provided must be valued. Experience with the traditional salary schedule suggests that teachers value pay rewards enough to collect years of seniority, credits, and degrees. But to motivate the acquisition of the new, possibly hard-to-master skills needed to improve instruction, the incentives must be of sufficient size to attract teachers' attention and to be perceived as commensurate with the effort needed to acquire the skills. It is reasonable to expect that the greater the size of the incentive, the more motivational effect, all else equal. So an important facet of this dimension is the size of the incentive offered.

To the extent that knowledge and skill rewards replace the traditional pay increases for seniority and educational attainment, we might expect teachers to be more motivated to attain the skills since the traditional opportunities for pay increases have been reduced. A more radical change in the pay structure, deemphasizing seniority and educational attainment unrelated to classroom instruction, sends a stronger signal that new knowledge and skills are needed. 
Knowledge and skill pay programs might be located on a continuum ranging from those that supplement the traditional salary schedule by simply adding additional pay opportunities based on knowledge and skill acquisition, to complete replacement of the traditional schedule's seniority steps and educational attainment lanes with a set of pay levels based only on knowledge and skill attainment. One might expect that the greater the perceived need to improve instruction, the more the traditional salary schedule would be modified and the larger the incentives for knowledge and skill acquisition would be.

A knowledge and skill-based pay system carries risks for teachers accustomed to automatic pay increases based on seniority. It may be particularly unattractive to more senior teachers because it places less emphasis on seniority as a criterion for pay differentiation, and can require developing new skills, which may not be as good an investment of effort for them. To get a knowledge and skill-based pay program accepted may require some provision that compensates teachers in some way for the increased risk or reduces the threat that the emphasis on new skills can represent to senior teachers. Thus, another feature of interest is whether the programs include provisions intended to make the new system acceptable to potential opponents such as veteran teachers.

\section{Alignment of Other Human Resource Programs in Support of the Knowledge and Skill Model}

Ensuring that the professional development programs available to teachers are aligned with the knowledge and skill model is likely to be a determinant of program success because, according to the motivational model, teachers need to perceive that opportunities to acquire the rewarded skills are available in order to believe that their efforts are likely to be successful. Private sector employers appear to take on the responsibility for providing and communicating opportunities to acquire skills, to ensure availability, and to show employees their efforts to acquire skills are being supported (American Compensation Association, 1996; Jenkins et al., 1992). Thus, an important aspect of alignment is whether organizations provide professional development opportunities linked to the knowledge and skills their pay systems reward.

A knowledge and skill model can also provide a foundation for other human resource management programs such as performance evaluation, recruitment, and selection (Spencer \& Spencer, 1993; Shippman et al., 2000). The theory of action postulates that a human resource management program aligned with the model will contribute to the development of a shared conception of good instruction consistent with the model. If the model is shared with job candidates during recruitment, those who do not believe that they can develop the skills or are not in agreement with the underlying philosophy of instruction may "selfselect" out of the hiring process. Selecting new teachers based on the knowledge and skill model helps to ensure those hired have the skills or the potential to develop them. If teachers select the district or school and the district or school selects teachers based on the model, convergence on the conception of instruction it embodies should increase over time. With respect to current staff, if teacher evaluation is made consistent with the knowledge and skill model, this will avoid confusing teachers about what 
it values as good teaching, and teachers will not be faced with two unrelated assessments on which they must spend time and energy. Teachers should be more likely to use the model to guide their own professional development efforts and to absorb the model as the appropriate way to think about teaching, again reinforcing a shared conception of instruction. Thus, a second aspect of alignment is the extent to which the knowledge and skill model is integrated with other human resource management programs besides pay and professional development.

\section{Costs and Funding}

While knowledge and skill-based pay offers substantial benefits, it is also likely to require additional investments, including the costs of increased professional development and additional administrative overhead (e.g., assessment and record-keeping) as well as higher salaries. Private sector experience with knowledge and skill-based pay programs suggests that administrative costs and per-employee salary costs increase (Gupta, Jenkins, \& Curington, 1986; Jenkins et al., 1992 ). Individual pay increases are thought to be offset by increases in productivity and greater flexibility in staff utilization due to crosstraining. However, these offsets are less likely to appear in the K-12 sector because increased productivity, in the form of higher student achievement, typically does not allow reductions in staff nor savings in materials or equipment. (Nor is it immediately marketable for increased revenue). The knowledge and skills are not those that allow teachers to do more different jobs, therefore allowing elimination of support staff. While some of the additional salary costs could be offset by lower pay for those who do not acquire the knowledge and skills emphasized by the program, the purpose of knowledge and skill-based pay has generally been to increase the skills of all or most employees, and as average skill level rises, so does pay. Therefore, in the long run, we would expect higher costs, which need to be funded by new money or reallocation of existing resources.

\section{Case Selection, Data, and Method}

The cases compared in this report include six school districts and one charter school all of which had adopted some form of knowledge and skill-based pay. The cases were selected based on project researchers' knowledge of districts or schools designing and implementing these pay programs, and a survey of state department of education and teacher association staffs which asked them to identify districts with innovative pay systems. These "early adopters" are not representative of U.S. schools or districts, but are merely illustrative of the variety of knowledge and skill-based pay programs that are being developed and of the process of design and implementation. Description and comparison is based on the programs' operation or design as of the 1999-2000 school year. In each case, project staff visited the district or school, in some cases multiple times, during the 19982000 period. Administrators, union officials, and in some instances, teachers were interviewed. A semi-structured interview protocol guided most of the interviews. Documents describing the program were also collected, and in some cases internal research done by the districts to evaluate the programs was obtained. The researcher who visited the site wrote a case description from which the information relevant to the comparison dimensions was abstracted. 
Appendix A provides a brief description of each case site. More extended case descriptions are available at www.wcer.wisc.edu/cpre. In a few cases, additional contacts were made by the author to clarify information in the case descriptions. The author then summarized the features of each case along the comparison dimensions, then attempted to identify patterns and important differences, and to draw conclusions about the implications of the experiences of these early adopters for research and program design.

\section{Program Comparisons}

The similarities and differences among the seven programs are presented below, structured according to the seven comparison dimensions.

\section{Motivation for Developing the Knowledge and Skill-based Pay Program}

The varied motivations for pay system change we found suggest that knowledge and skill-based pay was not simply seen as a way to improve student achievement through improving the skill level of current staff, as assumed by our theory of action. Though supporting improved instruction was a common goal, there were other important reasons for initiating change. It does not appear that most of these early adopters were primarily focused on using the programs to increase teachers' instructional capacity in order to improve student performance. Decision-makers at most of the sites did not appear to have based their programs on a theory of action like the one described above. Table 1 summarizes the key factors in each case.
In Cincinnati and Vaughn, cases where external accountability pressures emphasized the need to improve student achievement, the primary rationale for the programs was not expressed in terms of remedying a knowledge or skill deficit among current staff. Rather, the programs seemed to be intended to motivate staff to change practice and to reward more accomplished teaching. In Cincinnati, this was supplemented by dissatisfaction with the current teacher evaluation system and changes in the state licensing system. At Vaughn, the recruitment and retention of highly-skilled teachers was an important additional aim. In Robbinsdale, recognizing and rewarding accomplished teachers, and recruitment of skilled teachers, appear to have been the major goals. In Coventry, program designers wanted to differentiate teacher pay according to performance and to keep good teachers in the classroom as well as to support a particular vision of quality instruction. In Manitowoc, the superintendent's vision of quality instruction and his desire to provide incentives for teacher learning were joined by the union leadership's interest in improving pay while staying under state-imposed expenditure limits and supporting a professional development initiative developed by the state teachers' association. Both the superintendent and the association leadership wanted to improve retention, and begin adapting the pay system to state licensing changes. In Douglas County, knowledge and skillbased pay came about as part of a pay system redesign primarily intended to respond to public pressure to link teacher pay and teacher performance in order to improve accountability for the use of public funds. In Limon, the current program replaced one in which pay increases were based on individual teacher evaluations. Program designers there found a way to respond to public 
Table 1. Initiation of Knowledge and Skill-based Pay (KSBP) Design Process

\begin{tabular}{|c|c|c|c|c|}
\hline Site & $\begin{array}{l}\text { Primary Motivation for Developing } \\
\text { KSBP }\end{array}$ & $\begin{array}{l}\text { Supporting State Policy } \\
\text { Initiatives }\end{array}$ & Champion(s) & $\begin{array}{l}\text { Labor-Management } \\
\text { Relations }\end{array}$ \\
\hline Cincinnati & $\begin{array}{l}\text { Strategic planning process } \\
\text { identified KSBP as one district } \\
\text { strategy for improving student } \\
\text { achievement. }\end{array}$ & $\begin{array}{l}\text { State proficiency tests. } \\
\text { Change in state } \\
\text { licensing standards. }\end{array}$ & $\begin{array}{l}\text { Union Bargaining Chair, } \\
\text { Associate Superinten- } \\
\text { dent, outside } \\
\text { consultant from } \\
\text { university. }\end{array}$ & $\begin{array}{l}\text { Variable, but } \\
\text { underlain by trust } \\
\text { relationship between } \\
\text { key union and } \\
\text { management staff. }\end{array}$ \\
\hline Coventry & $\begin{array}{l}\text { Desire to differentiate pay according } \\
\text { to performance and support new } \\
\text { model of instruction. Secondarily, } \\
\text { concern about pay inequities } \\
\text { between junior and senior teachers; } \\
\text { desire to keep good teachers in the } \\
\text { classroom rather than moving to } \\
\text { administration to receive more } \\
\text { money. }\end{array}$ & $\begin{array}{l}\text { None directly, though } \\
\text { new state funding } \\
\text { formula may have } \\
\text { provided some of the } \\
\text { additional funds } \\
\text { needed. }\end{array}$ & $\begin{array}{l}\text { Superintendent, union } \\
\text { president. }\end{array}$ & $\begin{array}{l}\text { Cooperative, after } \\
\text { period of conflict in } \\
\text { the 1970s. }\end{array}$ \\
\hline $\begin{array}{l}\text { Douglas } \\
\text { County }\end{array}$ & $\begin{array}{l}\text { Part of broader compensation } \\
\text { redesign aimed at reassuring public } \\
\text { concerned about accountability for } \\
\text { use of public funds. }\end{array}$ & $\begin{array}{l}\text { State teacher licensing } \\
\text { reforms. }\end{array}$ & $\begin{array}{l}\text { Assistant } \\
\text { Superintendent for } \\
\text { Human Resources; } \\
\text { union president. }\end{array}$ & Cooperative. \\
\hline Limon & $\begin{array}{l}\text { Desire to link pay with teacher } \\
\text { performance coupled with teacher } \\
\text { dissatisfaction with prior individual } \\
\text { pay-for-performance system. Desire } \\
\text { to add group reward component } \\
\text { linked to state assessment results. }\end{array}$ & $\begin{array}{l}\text { State financial } \\
\text { incentives for local } \\
\text { districts to adopt pay- } \\
\text { for-performance } \\
\text { systems; state } \\
\text { assessment system. }\end{array}$ & $\begin{array}{l}\text { Superintendent initially, } \\
\text { then teachers. }\end{array}$ & $\begin{array}{l}\text { Basically cooperative, } \\
\text { due to new } \\
\text { superintendent and } \\
\text { relative weakness of } \\
\text { union in "right-to- } \\
\text { work" state. }\end{array}$ \\
\hline Manitowoc & $\begin{array}{l}\text { Desire to provide incentives for } \\
\text { teachers to develop their skills in } \\
\text { order to implement more } \\
\text { constructivist instruction; improve } \\
\text { teacher retention; support union- } \\
\text { initiated professional development } \\
\text { program. }\end{array}$ & State licensing reforms. & $\begin{array}{l}\text { Superintendent initially; } \\
\text { joined by regional union } \\
\text { representative. }\end{array}$ & $\begin{array}{l}\text { Cooperative; new } \\
\text { leaders changed } \\
\text { previous more } \\
\text { adversarial } \\
\text { relationship. }\end{array}$ \\
\hline Robbinsdale & $\begin{array}{l}\text { Concerns with recruiting and } \\
\text { retaining quality teachers in } \\
\text { competition with other local } \\
\text { districts; concern about pay } \\
\text { inequities between junior and senior } \\
\text { teachers. }\end{array}$ & None directly. & Union president. & $\begin{array}{l}\text { Cooperative, based } \\
\text { on stable district and } \\
\text { union leadership. }\end{array}$ \\
\hline Vaughn & $\begin{array}{l}\text { Part of broader compensation } \\
\text { redesign aimed at improving } \\
\text { recruitment and retention of good } \\
\text { teachers, desire to add teacher } \\
\text { accountability to external } \\
\text { accountability provided by charter, } \\
\text { and to address perceived pay } \\
\text { inequities between junior and senior } \\
\text { teachers. }\end{array}$ & $\begin{array}{l}\text { Charter status and } \\
\text { performance pressure } \\
\text { from explicit charter } \\
\text { goals. }\end{array}$ & $\begin{array}{l}\text { Principal, initially, then } \\
\text { junior teacher and } \\
\text { several more senior } \\
\text { staff. }\end{array}$ & $\begin{array}{l}\text { No union; relatively } \\
\text { high level of trust } \\
\text { between teachers } \\
\text { and administrators } \\
\text { based on } \\
\text { commitment to } \\
\text { charter, participatory } \\
\text { governance structure, } \\
\text { and charisma of } \\
\text { principal. }\end{array}$ \\
\hline
\end{tabular}


interest in linking pay to performance and teachers' concerns about unfairness of the old system by rewarding both individual professional development and meeting building and grade-level student achievement goals. Perceived inequities in the traditional salary schedule between younger, high-performing teachers and more senior teachers contributed to motivating pay system change in Coventry, Robbinsdale, and Vaughn. This is interesting given that one advantage often cited for the traditional salary schedule is that teachers perceive it to be highly equitable (Odden \& Kelley, 1997).

State policy, while not a primary driver of pay system change, was an important background condition in many of the cases. Teacher licensing policy provided a reinforcement for change in Cincinnati and Manitowoc. State incentives may have provided motivation for Limon's initial experimentation with non-traditional pay systems, and for the district to continue to include teacher and student performance elements in its current plan. But while all of the sites were in states with some form of student testing and accountability program, only the two sites with relatively low student achievement (Cincinnati and Vaughn) felt much pressure from these programs. In the others, student achievement was either relatively high or not a major issue in the other communities.

While in all of the cases, a champion or set of champions was important in keeping it going to a successful conclusion, in three cases the champion's own agenda was a key impetus to initiating change. In Coventry and Manitowoc, the programs were initiated partly to pursue the superintendent's personal vision of good instruction, though in Coventry the union president actually got discussion going by proposing rewards for National Board certification. In Robbinsdale, the former union president initiated discussions with the district based on his desire to ensure that new teachers who fit his conception of a good teacher would be available when it became necessary to replace retirees. At Vaughn, the principal began to explore pay innovations to strengthen teachers' sense of accountability for student performance by adding individual stakes to the overall external accountability provided in the charter. It is interesting that in four of the seven cases, a union official was one of the champions, and in a fifth, a Uniserve representative was a key catalyst of innovation. This suggests that teachers' unions can be supportive of changing the traditional salary structure. Where union and management relations are good, and a high-trust relationship exists between union leaders and at least some management leaders, it appears that teacher compensation innovation can be successfully initiated.

\section{Process Used to Design the Program}

Table 2 summarizes three key aspects of the design process at these sites: the type and level of teacher participation in design, the relationship to the collective bargaining process, and the methods used to identify the knowledge and skills to be rewarded.

Teacher participation. Large-scale teacher participation in the design process was present in the three largest organizations (Cincinnati, Douglas County, and Robbinsdale). In these districts, a formal committee process was used to involve a substantial number of teachers in some aspect of system design. These cases suggest that broad teacher 


\section{Table 2. Characteristics of Knowledge and Skill-based Pay Design Process}

\begin{tabular}{|c|c|c|c|}
\hline Site & $\begin{array}{l}\text { Relationship to the Collective } \\
\text { Bargaining Process }\end{array}$ & $\begin{array}{l}\text { Type/Level of Teacher } \\
\text { Participation }\end{array}$ & $\begin{array}{l}\text { Method of Knowledge and Skill } \\
\text { Identification }\end{array}$ \\
\hline Cincinnati & $\begin{array}{l}\text { Commitment to develop plan } \\
\text { agreed to in contract. Design } \\
\text { process took place outside normal } \\
\text { collective bargaining though system } \\
\text { of union-management committees. } \\
\text { Steering committee jointly chaired } \\
\text { by union and management } \\
\text { representatives. Teachers voted to } \\
\text { approve contract including the } \\
\text { results, and have opportunity to } \\
\text { vote out system before September } \\
2002 \text { implementation. }\end{array}$ & $\begin{array}{l}\text { Twenty-four teachers from a variety } \\
\text { of schools participated on the } \\
\text { various committees. }\end{array}$ & $\begin{array}{l}\text { Adaptation of standards for teacher } \\
\text { performance found in the Framework for } \\
\text { Teaching (Danielson, 1996). }\end{array}$ \\
\hline Coventry & $\begin{array}{l}\text { Worked out as part of interest- } \\
\text { based bargaining process. }\end{array}$ & $\begin{array}{l}\text { Limited to members of bargaining } \\
\text { team, though rank-and-file teachers } \\
\text { participated in design of the teacher } \\
\text { evaluation system incorporated into } \\
\text { the plan. }\end{array}$ & $\begin{array}{l}\text { Adaptation of National Board for } \\
\text { Professional Teaching Standards for one } \\
\text { pay incentive; inductive process drew } \\
\text { from best practice literature (including } \\
\text { work of Sizer and Newmann) and district } \\
\text { action research for the other. }\end{array}$ \\
\hline $\begin{array}{l}\text { Douglas } \\
\text { County }\end{array}$ & $\begin{array}{l}\text { Commitment to develop plan } \\
\text { agreed to in contract. Design } \\
\text { process took place outside normal } \\
\text { bargaining via a } 30 \text {-member } \\
\text { performance pay committee. }\end{array}$ & $\begin{array}{l}\text { Performance pay committee } \\
\text { included } 20 \text { teachers from a cross- } \\
\text { section of union members. }\end{array}$ & $\begin{array}{l}\text { Deductive and inductive processes used } \\
\text { to develop skill blocks; adaptation of } \\
\text { National Board standards and Colorado } \\
\text { licensing standards for the outstanding } \\
\text { teacher award. }\end{array}$ \\
\hline Limon & $\begin{array}{l}\text { No formal contract. Program } \\
\text { concept developed by } \\
\text { superintendent and teacher } \\
\text { representatives as part of informal } \\
\text { negotiations. School board passed } \\
\text { proposal and teachers' association } \\
\text { agreed to try proposal. }\end{array}$ & $\begin{array}{l}\text { Three teachers worked with } \\
\text { superintendent to develop concept; } \\
\text { detail design done by a committee } \\
\text { with seven teachers and one } \\
\text { administrator. }\end{array}$ & $\begin{array}{l}\text { Left to teacher and building administrator, } \\
\text { based on district-provided guidelines. }\end{array}$ \\
\hline Manitowoc & $\begin{array}{l}\text { Worked out as part of interest- } \\
\text { based bargaining process and } \\
\text { approved as part of teacher } \\
\text { contract. }\end{array}$ & $\begin{array}{l}\text { Eight association bargaining team } \\
\text { members participated as part of } \\
\text { bargaining process. }\end{array}$ & $\begin{array}{l}\text { Inductive, based on education research; } \\
\text { adoption of National Board standards. }\end{array}$ \\
\hline Robbinsdale & $\begin{array}{l}\text { Initial concept and outline of skill } \\
\text { areas and pay levels agreed to in } \\
\text { bargaining. Detail design by set of } \\
\text { union-management committees. }\end{array}$ & $\begin{array}{l}\text { A few teachers participated as } \\
\text { members of the bargaining team. } \\
\text { More teachers participated as } \\
\text { members of each of eight } \\
\text { committees responsible for defining } \\
\text { skill levels and methods of } \\
\text { assessment. }\end{array}$ & $\begin{array}{l}\text { Adoption of National Board standards; } \\
\text { induction from research and experience. }\end{array}$ \\
\hline Vaughn & No collective bargaining. & $\begin{array}{l}\text { Design by small group of teachers } \\
\text { and administrators, then extensive } \\
\text { discussions via informational } \\
\text { meetings in committees of } \\
\text { governance structure. }\end{array}$ & $\begin{array}{l}\text { Primarily deductive from educational } \\
\text { goals in charter, with some adaptation of } \\
\text { the Framework for Teaching for the } \\
\text { rubrics. }\end{array}$ \\
\hline
\end{tabular}


involvement can have a substantial influence on the content of the plan. For example, in Cincinnati, teachers on the committees probed for ambiguities in the design proposals and contributed specific ideas for design, as well as pushed for provisions to reassure teachers about fairness. The input of National Boardcertified teachers was influential in persuading other teachers on the committee to take the risk of trying a new system of evaluation and pay. Of the smaller organizations, Limon provided for relatively extensive participation given the size of the district, while in Coventry and Manitowoc, teacher participation appeared limited to the association bargaining team. A relatively small group developed the Vaughn plan, though it was adopted by a vote of the governance committee on which teachers were heavily represented and after considerable formal and informal discussion among the faculty. However, involving a substantial number of teachers does not guarantee broad communication. Outside evaluations of both Douglas County (Hall \& Caffellera, 1997) and Cincinnati (Milanowski \& Kellor, 2000a) suggest that many teachers who had not been active participants in the design process did not seem informed of some aspects of the systems. In Cincinnati, the large size of the district and the complexity of the program seemed to require more intensive districtor association-sponsored communications efforts than were initially undertaken.

Relationship to collective bargaining. As expected, none of the programs were developed through traditional adversarial collective bargaining. It was also expected that knowledge and skill-based pay programs would be too complex and time-consuming to work out in detail through the normal negotiation process. However, in three of the cases, the details of the process were worked out within the negotiation process. It appears that pay changes of substantial complexity can be developed in the bargaining process as long as the parties have achieved a high level of trust and focus on a vision or desired goal shared by both sides. Where the programs' details were bargained, a clear sense emerges from the case studies that the shared vision or goal was an important influence in keeping the discussions from getting sidetracked by issues of who gains and who loses from particular details of the program.

\section{Knowledge and skill identification.}

There was no one method of knowledge and skill identification that dominated in these cases. As expected, many programs made use of existing standards or definitions of good teaching. In five of the seven cases, an external set of teacher standards, either the NBPTS or the Framework for Teaching (Danielson, 1996), were influential. Cincinnati is the clearest example of adaptation. Starting with the Framework for Teaching, the design committee examined each component and revised wording to fit the district context. Adapting the Framework for Teaching allowed the district to design a system in a relatively short time. In contrast, Robbinsdale, though beginning with NBPTS standards and making Board certification a major determinant of knowledge and skillbased pay increases, had not been able to implement its system in the school year intended in part because of the difficulty in defining the key indicators of knowledge and skill in the parts of its system not related to the NBPTS standards. In Coventry, the Framework for Teaching is the basis for the teacher evaluation system, but the pay incentives are based on separate standards. One provision is based on the NBPTS certification, and the other on locally- 
developed criteria with content that differs from both Framework and the Board's standards. The programs in Douglas County, Limon, Manitowoc, and Vaughn were not primarily based on existing external standards, though Vaughn did adapt the format of the Framework for Teaching's rubrics. The strengths and weaknesses of the deductive approach are illustrated by the Vaughn case. The knowledge and skills developed were closely tied to school goals, so they had the potential to focus all teachers on key skills. However, the process of identifying the skills and the standards for measuring them was difficult and time consuming. As a consequence, in the first year, the criteria for knowledge and skill demonstration were not well specified, causing many of the initial participants to have concerns about fairness of application (Milanowski \& Kellor, 1999). These experiences suggest that adapting an existing model of teacher practice may be the most efficient way to get a knowledge and skill-based pay system up and running.

\section{Knowledge and Skills Rewarded and their Organization into a Structure}

Table 3 summarizes the knowledge and skills rewarded in the cases, and how the knowledge and skills were organized into some form of developmental sequence or set of performance levels. As expected, all programs rewarded knowledge and skills relevant to instruction, especially pedagogical skills. There are differences in emphasis, however. Coventry, Douglas County's skill blocks, and Manitowoc appeared to be trying to promote constructivist or "authentic" instruction, while Cincinnati and Vaughn were concerned with a more generic model of good teaching, though with some constructivist elements. Limon allowed the teacher and/or building administrator to determine what sort of instructional skills should be developed within broad district guidelines.

Robbinsdale had not yet worked out its model in detail at the time of our study. None of the programs appeared to emphasize mastery of content-specific pedagogy (Shulman, 1987; National Commission on Teaching and America's Future, 1996), except as embodied in NBPTS certification, though some of Cincinnati's and Coventry's locallydeveloped rubrics referenced it and some of Vaughn's represented basic aspects of it.

Most of the programs are eclectic in the way they specify what knowledge and skills are rewarded. While most of the rewards in the Cincinnati and Vaughn programs are based on developing knowledge and skills that are described in terms of teaching behaviors or skilled performance, there is some reward provided for degrees or certifications analogous to the credits in the traditional schedule. Another set of programs Douglas County, Coventry, and Robbinsdale - mixed external certifications with more or less detailed descriptions of desired performance or behavior. Limon provided relatively little guidance, leaving the teacher and administrator wide leeway as to the knowledge and skills to be developed. The Manitowoc program specified its knowledge and skills in terms of courses and certifications, analogous to degrees and credits, rather than describing behaviors or skills.

In only a few of the programs, most notably those of Cincinnati and Vaughn, did the knowledge and skills specified approach the ideal of an integrated developmental sequence or structure of levels. The other programs had not 


\section{Table 3. Knowledge and Skills Rewarded: Content and Structure}

\begin{tabular}{|c|c|c|}
\hline Site & Knowledge and Skill Domains Identified & Developmental Levels of Knowledge and Skills \\
\hline Cincinnati & $\begin{array}{l}\text { Three-part system: (1) four core domains: } \\
\text { planning and preparing for student learning, } \\
\text { creating an environment for learning, teaching for } \\
\text { learning, and professionalism; specific behavioral } \\
\text { standards in each domain with rubrics describing } \\
\text { four levels of performance on each standard; (2) } \\
\text { content knowledge; (3) NBPTS standards.* }\end{array}$ & $\begin{array}{l}\text { Core of system had five developmental or career levels; } \\
\text { aggregation of rubric scores on standards define career level. }\end{array}$ \\
\hline $\begin{array}{l}\text { Douglas } \\
\text { County }\end{array}$ & $\begin{array}{l}\text { Two-part system: (1) nine skill blocks covering } \\
\text { technology, authentic assessment, and diversity; } \\
\text { (2) outstanding teacher award with options using: } \\
\text { (a) NBPTS standards; (b) standards-based } \\
\text { instruction; or (c) assessment and instruction, } \\
\text { content and pedagogy, and collaboration. } \\
\text { Standards for outstanding teacher were a mixture } \\
\text { of knowledge and skill descriptions and } \\
\text { descriptions of behavior. }\end{array}$ & $\begin{array}{l}\text { Two separate programs with limited overlap; some of the skill } \\
\text { blocks represent developmental sequences. }\end{array}$ \\
\hline Limon & $\begin{array}{l}\text { Program did not specify knowledge and skills to } \\
\text { be sought, leaving this up to teacher and } \\
\text { administrator based on general guidelines that } \\
\text { emphasized the need to focus on instruction and } \\
\text { student learning. }\end{array}$ & $\begin{array}{l}\text { Unstructured; content and sequence open to development by } \\
\text { teacher and administrator. }\end{array}$ \\
\hline Manitowoc & $\begin{array}{l}\text { Three aspects of system: (1) district-developed } \\
\text { courses covering authentic instruction, } \\
\text { technology, writing instruction; (2) NBPTS } \\
\text { standards:* (3) content knowledge represented } \\
\text { by degrees and credits. Knowledge and skills } \\
\text { primarily defined in terms of courses and } \\
\text { certifications. }\end{array}$ & $\begin{array}{l}\text { Program components are independent; no developmental } \\
\text { levels identified at time of study, though district courses and } \\
\text { Professional Development Certificate could prepare teacher } \\
\text { for Board certification. }\end{array}$ \\
\hline Vaughn & $\begin{array}{l}\text { Core system based on } 11 \text { locally-defined domains } \\
\text { of skill in lesson planning and classroom } \\
\text { management, literacy, language development, } \\
\text { technology, special education inclusion, } \\
\text { mathematics, history and social science, and } \\
\text { science pedagogy, instruction in primary language } \\
\text { for English learners, arts. Additional knowledge } \\
\text { and skills rewarded defined by NBPTS standards, * } \\
\text { Master's degree, state licensure level. }\end{array}$ & $\begin{array}{l}\text { Core of system defined three levels for additional pay: level } \\
\text { one based on achieving an average rubric score of } 2.5 \text { in six } \\
\text { of the "essential" domains; level two required an average of } \\
\text { three in those domains, then provides additional pay for rubric } \\
\text { score of three in any of five additional domains; level three } \\
\text { based on achieving an average rubric score of } 3.5 \text { in all } \\
\text { domains. }\end{array}$ \\
\hline
\end{tabular}

\footnotetext{
* The content of the National Board standards varies by subject and level among the 30+ certifications offered; however, almost all standards include the domains of knowledge of students, knowledge of subject, knowledge of pedagogy, creating a learning environment, use of a variety of assessment methods, reflection on practice, and collaboration with parents and colleagues.
} 
organized the knowledge and skills into a core set of standards, nor provided a continuum of skill development that unified the knowledge and skill domains along a developmental path or career progression. Even the Cincinnati and Vaughn programs did not appear to integrate their local standards with the National Board standards, treating Board certification as an additional credential like a Master's degree rather than as another developmental level. Though the programs in Coventry and Manitowoc were informed by a coherent vision of instruction on the part of their original champions, these programs did not include a developmental progression linked with pay increases at the time we studied them.

\section{How Knowledge and Skill Acquisition was Assessed}

Table 4 summarizes the assessment methods used in each of the seven programs, including the use of external assessments. All use some form of performance assessment, though the extent to which these assessments are central to the program varies. The Cincinnati and Vaughn assessment systems were primarily based on demonstrating knowledge and skills via classroom performance and are part of the regular teacher evaluation. Programs that use National Board certification as a criteria for pay increases (Manitowoc, Robbinsdale, and Coventry) incorporated the performance emphasis of the Board's assessments. Coventry also used a performance-based approach in its local assessments. The assessments at the end of Douglas County's skill blocks are performance-based, though performance in training is not always the same as classroom performance. The guidelines for the Limon process emphasized connecting the professional development documented in the portfolio to classroom practice and student learning, though it is up to the teacher and administrator to implement these guidelines. One of Robbinsdale's performance dimensions involved principal evaluation via classroom observation, and several others are based on real-world accomplishments rather than degrees or credits. The observations were to be part of the regular teacher evaluation process, and the results add one element in a teacher portfolio that documents knowledge and skill. Manitowoc's program mostly relied on indirect evidence like certifications and course attendance, more analogous to the traditional degrees and credits.

Performance assessment was incorporated mostly through the incentive provided for National Board certification.

Use of external assessments. Five of the seven programs included the NBPTS assessments. However, these assessments were not typically integrated with the local assessment system, nor used as a measure of core teaching skills. In most cases, the NBPTS assessment was included because of pay incentives for NBPTS certification, which in turn was treated as an additional degree rather than as an integral part of the knowledge and skill model. The exceptions are Coventry and Robbinsdale. In Coventry, while the domains measured by the local and Board assessments differ, the processes are similar with the local process designed to help teachers prepare for the Board assessment. In Robbinsdale, the NBPTS assessment was the criterion for a sizable part of the knowledge and skill pay incentive and seemed to form the conceptual anchor for the program, but there were several other locallyassessed ways for teachers to demonstrate knowledge and skill in order to increase their pay. 
Table 4. Methods of Assessment

\begin{tabular}{|c|c|c|}
\hline Site & Locally-developed Assessments Used & $\begin{array}{l}\text { External Assessments } \\
\text { Used }\end{array}$ \\
\hline Cincinnati & $\begin{array}{l}\text { Internal assessment of performance in the four primary knowledge } \\
\text { and skill domains by site administrators and peer evaluators with } \\
\text { subject expertise. Types of evidence: six classroom observations; } \\
\text { portfolio including artifacts such as lesson plans, student work, } \\
\text { parent contact logs, professional development logs. }\end{array}$ & $\begin{array}{l}\text { NBPTS assessment, degree } \\
\text { completion, and licensure will } \\
\text { be used to determine eligibility } \\
\text { for additional pay elements. }\end{array}$ \\
\hline \multirow[t]{2}{*}{ Coventry } & $\begin{array}{l}\text { Internal assessment based on a teacher-prepared portfolio used for } \\
\text { the RHODE program. Portfolio including evidence that/of: teachers } \\
\text { know students, have prepared for and practiced differentiated } \\
\text { learning, ability to motivate and support all students, family, and } \\
\text { community contact, and professional development. Also self-analysis } \\
\text { of teaching and assessment of student work. }\end{array}$ & $\begin{array}{l}\text { NBPTS assessment used for } \\
\text { pay increment for NBPTS } \\
\text { certification. }\end{array}$ \\
\hline & $\begin{array}{l}\text { RHODE: Nine-element portfolio evaluated using rubrics. Each } \\
\text { element scored for evidence of presence of five behaviors or } \\
\text { outcomes each worth one point. Total score of } 43 \text { points qualifies for } \\
\text { award. }\end{array}$ & \\
\hline Douglas County & $\begin{array}{l}\text { Performance-based assessment at end of each skill block done by } \\
\text { course instructors. No specific rubrics or standards defined } \\
\text { outstanding teacher; review of portfolio prepared for outstanding } \\
\text { teacher award done by administrators. }\end{array}$ & Not applicable. \\
\hline Limon & $\begin{array}{l}\text { Portfolio documenting activities toward fulfilling professional growth } \\
\text { goal evaluated by administrators. No specific rubrics or standards to } \\
\text { evaluate skill acquisition. }\end{array}$ & Not applicable. \\
\hline Manitowoc & $\begin{array}{l}\text { Mixture of external (NBPTS, Professional Development Certificate, } \\
\text { degrees) and internal (local teacher-taught courses) opportunities. } \\
\text { Standards or rubrics used to evaluate skill acquisition depended on } \\
\text { course or certification. }\end{array}$ & $\begin{array}{l}\text { Grades/degrees/certifications } \\
\text { from higher education. NBPTS } \\
\text { assessment used for pay } \\
\text { element rewarding NBPTS } \\
\text { certification. }\end{array}$ \\
\hline Robbinsdale & $\begin{array}{l}\text { Documentation of achievements via portfolio, classroom } \\
\text { observations; student/parent surveys. Evidence evaluated by } \\
\text { committee consisting of three appointees of superintendent, three } \\
\text { appointees of union president. Specific rubrics/guidelines remained } \\
\text { to be developed for most domains. }\end{array}$ & $\begin{array}{l}\text { NBPTS assessment used for } \\
\text { pay element rewarding NBPTS } \\
\text { certification. }\end{array}$ \\
\hline Vaughn & $\begin{array}{l}\text { Classroom observations, artifacts such as lesson plans and student } \\
\text { work evaluated by an administrator, grade-level peer, and self. Four- } \\
\text { level rubrics used specific behavioral examples to define levels of } \\
\text { performance in each domain. }\end{array}$ & $\begin{array}{l}\text { Grades/degrees/certifications } \\
\text { from higher education used for } \\
\text { pay elements rewarding } \\
\text { credentialing. NBPTS } \\
\text { assessment used for pay } \\
\text { increment for NBPTS } \\
\text { certification. }\end{array}$ \\
\hline
\end{tabular}

Validity and reliability. According to the theory of action, knowledge and skill-based pay programs require methods of assessment that are valid and reliable, and recognized as such by teachers. At the time of our studies, little information was available about the validity or reliability of the assessments in any of the programs. From the information available, it appears that the most common external assessments, those of the NBPTS, have at least as much reliability and validity as many accepted human resource selection and evaluation techniques (Milanowski, Odden, \& Youngs, 1998; Jaeger, 1998). Only Cincinnati and Vaughn appeared to have confronted these issues with respect to their locally-developed assessments. Both have looked at the inter-rater agreement of their internal assessment systems and have been 
relatively satisfied that an acceptable level of agreement exists. At this point, no district has looked at the relationship between its assessments and independent measures of teacher performance, such as student achievement, though at least two were planning to explore this connection.

Information on teacher perceptions of the fairness of these assessments was available for three cases. In Cincinnati, teachers participating in the field test of the assessment system generally believed that the results of the process were fair, but many had concerns about the fairness of the process, especially with respect to administrator qualifications and the consistency of rating across administrators (Milanowski \& Kellor, 2000a). At Vaughn, in the initial year, many of the teachers covered by the system had concerns about the consistency of the evaluations and the difficulties evaluators had in making the requisite number of classroom observations (Milanowski \& Kellor, 1999). After the rubrics were more fully developed and problems with scheduling of observations addressed in the second year, fairness perceptions improved substantially (Milanowski \& Kellor, 2000b). In Douglas County, while fairness perceptions were not explicitly assessed, Hall and Caffarella (1997) did interview and survey teachers about their reactions to the program. Teachers did not identify fairness concerns as a major issue, though several teachers did mention problems such as subjectivity in the evaluation of the teacher portfolios. It may be that the lack of expressed fairness concerns was due to the lower stakes of the assessments for individual teachers (due to the relatively small dollar amounts associated with the skill blocks and the outstanding teacher award) and the fact that individual teachers could choose to participate or not.

\section{Size and Structure of Knowledge and Skill Incentives}

Table 5 describes the programs' knowledge and skill-based pay structures. The programs can be roughly categorized as falling into three groups: those that have essentially replaced the traditional schedule (Cincinnati, Limon); those that have modified the schedule, typically by reducing the importance of degrees and credits in exchange for more performance-oriented representations of knowledge and skill (Vaughn, Robbinsdale); and those that have supplemented the traditional design by adding knowledge and skillbased elements (Coventry, Douglas County, Manitowoc). We expected that organizations feeling more pressure to improve student achievement would be more likely to modify or replace the traditional schedule, but the association is not that strong. Cincinnati and Vaughn fit the pattern of organizations under pressure implementing major pay change, and Coventry, Douglas County, and Manitowoc fit the pattern of less pressure and more incremental change. Limon was an exception in that it replaced the traditional schedule completely, but for reasons other than providing a stronger incentive for knowledge and skill acquisition. Robbinsdale was another exception, with a relatively major pay system change but little pressure to improve student achievement. It should be noted that the potential impact of the more radical changes represented by the Robbinsdale and Vaughn pay systems was offset by limitations on who is covered by the new system. To allay apprehension on the part of senior 


\section{Table 5. Knowledge and Skill Pay Provisions and Relative Size of Incentive}

\begin{tabular}{|c|c|c|c|}
\hline Site & Pay Provisions & $\begin{array}{l}\text { KSBP Incentive as } \\
\text { Percent of Beginning } \\
\text { Base and Maximum } \\
\text { Salary }\end{array}$ & $\begin{array}{l}\text { Provisions to Win Teacher } \\
\text { Acceptance }\end{array}$ \\
\hline Cincinnati & $\begin{array}{l}\text { Core program: Five career levels of teaching practice with } \\
\text { salary ranges of } \$ 30,000, \$ 32,000-\$ 35,750, \$ 38,750- \\
\$ 49,250, \$ 52,500-\$ 55,000 \text {, and } \$ 60,000-\$ 62,500 ; \\
\text { movement between levels based on knowledge and skill } \\
\text { assessment, movement within levels through a limited } \\
\text { number of steps based on seniority; additional base pay add- } \\
\text { ons of } \$ 4,600 \text { for Master's degree, } \$ 9,375 \text { for Ph.D.; } \$ 1,250 \\
\text { for dual certification, } \$ 1,000 \text { for NBPTS certification, up to } \\
\$ 4,000 \text { (time-limited) for skill blocks. }\end{array}$ & $\begin{array}{l}\text { Base: } 60.8 \% \\
\text { Maximum: } 23.4 \%\end{array}$ & $\begin{array}{l}\text { High seniority teachers ( } 22 \text { years and up) } \\
\text { can remain on old salary schedule or can } \\
\text { volunteer to participate in new system. }\end{array}$ \\
\hline Coventry & $\begin{array}{l}\text { Traditional seniority and credits schedule supplemented by } \\
\$ 6,500 \text { add-on for life of NBPTS certification; } \$ 1,000 \text { per year } \\
\text { for four years based on achieving a cut-off score on a locally- } \\
\text { assessed portfolio (RHODE program). }\end{array}$ & $\begin{array}{l}\text { Base: } 22.8 \% \\
(19.8 \% \text { for NBPTS, } 3 \% \\
\text { for RHODE) } \\
\text { Maximum: } 9.7 \% \\
(8.4 \% \text { for NBPTS, } 1.3 \% \\
\text { for RHODE) }\end{array}$ & $\begin{array}{l}\text { Improved district contribution to teacher } \\
\text { retirement plan; early retirement option. }\end{array}$ \\
\hline $\begin{array}{l}\text { Douglas } \\
\text { County }\end{array}$ & $\begin{array}{l}\$ 300-\$ 500 \text { bonuses per skill block for nine blocks; } \$ 1,000 \\
\text { annual bonus for being designated an outstanding teacher. }\end{array}$ & $\begin{array}{l}\text { Base: } 17.4 \% \\
\text { Maximum: } 6.9 \%\end{array}$ & $\begin{array}{l}\text { Three percent across-the-board pay } \\
\text { increase; knowledge and skill part of plan } \\
\text { voluntary. }\end{array}$ \\
\hline Limon & $\begin{array}{l}\text { Entry pay based on a traditional seniority and credits } \\
\text { schedule, but after entry progression based on an across-the- } \\
\text { board increase, } \$ 1,000 \text { for a Master's and } \$ 3,000 \text { for a } \\
\text { Ph.D., plus up to } \$ 1,200 \text { in performance-based increases, } \\
\$ 400 \text { of which is based on meeting individual professional } \\
\text { development goals. }\end{array}$ & $\begin{array}{l}\text { Base: } 1.5 \% \\
\text { Maximum: } 1.0 \%\end{array}$ & $\begin{array}{l}\text { Cost-of-living adjustment added to pay } \\
\text { system, rectification of base pay } \\
\text { inequities between new hires and more } \\
\text { senior teachers. }\end{array}$ \\
\hline Manitowoc & $\begin{array}{l}\text { Expanded traditional salary schedule to provide more lanes } \\
\text { and allow movement between lanes based on locally- } \\
\text { developed courses and classroom-relevant university } \\
\text { certification aligned to NBPTS, as well as traditional credits } \\
\text { and degrees; } 13 \% \text { salary add-ons for NBPTS certification and } \\
\text { Ph.D. degree. Seniority movement within a lane capped at } \\
\text { lower pay levels to encourage obtaining advanced degrees } \\
\text { and other recognized professional development. }\end{array}$ & $\begin{array}{l}\text { Base: } 13 \% \text { NBPTS } \\
\text { Not applicable other } \\
\text { parts } \\
\text { Maximum: } 13 \% \text { NBPTS } \\
\text { Not applicable other } \\
\text { parts }\end{array}$ & $\begin{array}{l}\text { Improved funding of retiree health } \\
\text { insurance premiums; new pay elements } \\
\text { not covered by cost controls. }\end{array}$ \\
\hline Robbinsdale & $\begin{array}{l}\text { Traditional salary schedule modified by reducing number of } \\
\text { lanes from } 11 \text { to } 4 \text { and steps from } 13 \text { to } 7 . \text { Knowledge and } \\
\text { skill-based component provided for additional pay of up to } \\
\$ 15,000 \text {, with the actual amount based on points earned in } \\
\text { the following categories: NBPTS certification, principal } \\
\text { evaluation, individual accomplishments, district projects, } \\
\text { contribution to teams, content knowledge, professional } \\
\text { leadership, and customer satisfaction. }\end{array}$ & $\begin{array}{l}\text { Base: } 56.1 \% \\
\text { Maximum: } 23.8 \%\end{array}$ & $\begin{array}{l}\text { To be applied to newly-hired teachers or } \\
\text { volunteers. }\end{array}$ \\
\hline Vaughn & $\begin{array}{l}\text { One } 11 \text {-step seniority-based lane, } \$ 1,000 \text { add-on for } \\
\text { California teaching credential, } \$ 2,000 \text { add-on for Master's } \\
\text { degree, } \$ 2,000 \text { add-on for qualifying as demonstrator for } \\
\text { student teachers, } \$ 4,000 \text { add-on for NBPTS certification. } \\
\text { Three levels of competency-based pay add-ons (up to } \\
\$ 13,100 \text { ) earned by achieving a minimum score or better on } \\
\text { rubrics in } 10 \text { areas: Lesson planning and classroom } \\
\text { management, literacy, language development, technology, } \\
\text { special education inclusion, mathematics, history and social } \\
\text { science, science pedagogy, instruction in primary language for } \\
\text { English learners, arts. }\end{array}$ & $\begin{array}{l}\text { Base: } 48.7 \% \\
\text { Maximum: } 22.7 \%\end{array}$ & $\begin{array}{l}\text { Applied only to newly-hired teachers or } \\
\text { volunteers from among veteran teachers. }\end{array}$ \\
\hline
\end{tabular}


teachers socialized to the traditional system, these two programs required that only new or less senior teachers participate, leaving others on the traditional schedule.

In all of the cases, some sort of quid pro quo or provision was added to sell the program, especially to highly senior teachers. It is interesting that in two of the cases, the consideration was relatively small. In Manitowoc, it was an additional district contribution toward retiree health insurance premiums. In Cincinnati, it was the exemption of a relatively small number of very senior teachers who would be likely to retire soon after the pay provisions took effect. In four cases (Robbinsdale, Vaughn, Douglas County, and Coventry), participation in the knowledge and skill-based pay part of the system was voluntary for all or senior teachers (though at Vaughn most of the senior teachers opted into the system in the second year). In Coventry, the district also increased its contribution to the teacher retirement plan and provided an early retirement option. In Limon, a small cost-of-living adjustment was added to the pay system, and the school board corrected some base pay inequities that had emerged between new hires and more senior teachers. These experiences suggest that the potential opposition of senior teachers was an important issue to program designers. However, limiting the program to new teachers or volunteers may dilute the impact of the program on motivating improvements in instructional capacity. At Vaughn, the hope of the program's designers was that experienced teachers would volunteer to participate, and many did in the second year. In Robbinsdale, this was not a major concern because the primary impetus for designing the system was not to improve the skills of current teachers.

Both base pay increases and bonuses were used to reward knowledge and skill acquisition. Cincinnati, Coventry, Limon, Manitowoc, and Robbinsdale relied primarily on base pay increases, while the Vaughn and Douglas County knowledge and skill-based pay programs used bonuses. In some of the cases, however, some or all of the base pay increases were time limited "addons": the pay increase continued only for a fixed period, after which knowledge and skills had to be redemonstrated. The programs that rewarded NBPTS certification provided the extra pay for the 10-year life of the certification. Increases based on locallyassessed knowledge and skills were provided for four to five years in three cases. At Vaughn, the base/bonus distinction was blurred because the bonuses are pro-rated and the extra pay is included as an add-on to the monthly base. This provided continuity of income for teachers, though the extra money needs to be re-earned every year.

Though the pay systems in these cases were diverse, one notable similarity across them was that six retained a seniority-based element. (Limon eliminated seniority as a basis for progression after entry.) In this regard, most of these programs differed from private sector implementations of the knowledge and skill pay concept, which typically eliminates seniority as a basis for pay (Jenkins et al., 1992).

However, in five of the cases where seniority increases remained, the new pay system decreased the emphasis on seniority by reducing the number of seniority steps or capping senioritybased pay progression at a lower level. Another similarity was that all of the 
systems continue to reward Master's degrees, suggesting that the K-12 sector continues to value higher educational attainment, and that moving away from this traditional valuation may be too radical a change to be accepted by teachers. It should be noted, however, that Cincinnati planned to limit pay increases for Master's degrees to those relevant to the teaching assignment.

The motivation model suggests that, all else equal, more substantial incentives will be more effective in motivating knowledge and skill acquisition. One way to assess the size of the incentive is to compare it to the entry-level salary rate and to the maximum salary pay a teacher can earn in a school or district. Table 5 contains estimates of the magnitude of the knowledge and skill incentive in the form of the percentage available for knowledge and skill-based elements (beyond those recognized in the traditional salary structure) as a percentage of the beginning base pay and as a percentage of the highest pay rate available (including the knowledge and skill-based incentive, but exclusive of pay for additional activities like coaching). Again, significant variation existed, but it is clear that in three cases - Cincinnati, Robbinsdale, and Vaughn - the knowledge and skill incentive was substantial. The incentives provided by these three, as a percent of beginning pay, were on the order of those reported for private sector plans, which provide for $50 \%$ to $100 \%$ increases based on knowledge and skills (Gupta, Jenkins, \& Curington, 1986; Jenkins et al., 1992; Tucker \& Cofsky, 1994.) The expectation that a larger incentive would be found where the motivation for implementation was to improve student achievement was partially fulfilled in that some of the largest incentives were provided by Cincinnati and Vaughn. However, recruiting good teachers was the primary motivation in Robbinsdale, the other organization with a large incentive.

\section{How the Acquisition of the Knowledge and Skills are Supported}

Table 6 summarizes the professional development associated with the knowledge and skill-based pay programs, and the links between knowledge and skill-based pay and other aspects of the human resource management system.

At the time of our study, it did not appear that many of the programs had a strong professional development component specifically designed to provide teachers with the knowledge and skills rewarded. Those programs with larger incentives and more radical structures had not yet developed corresponding comprehensive professional development programs. Vaughn had only begun to develop a comprehensive professional development program linked to the specific skills in the model. Formal professional development was provided on some domains, including literacy and classroom management, and mentoring and teaming were beginning to be used to help develop skills in the program domains. Cincinnati, though it had a comprehensive knowledge and skill model, had not yet modified its fairly extensive professional development program to link up with it. Robbinsdale's model was not yet fully fleshed out, but the diversity of the elements rewarded (ranging from principal evaluation to professional leadership and parent satisfaction) 


\section{Table 6. Integration with Professional Development and Other Human Resource Management Programs}

\begin{tabular}{|c|c|}
\hline Site & $\begin{array}{l}\text { District Support for Acquiring the Knowledge and } \\
\text { Skills Needed }\end{array}$ \\
\hline Cincinnati & $\begin{array}{l}\text { While the district had an extensive professional } \\
\text { development program covering many of the skills relevant } \\
\text { to the teaching standards, there was no explicit linkage } \\
\text { between the program and the standards that would allow } \\
\text { teachers to determine which courses applied to each } \\
\text { standard. District had new teacher mentoring and peer } \\
\text { review programs that were being converted to use the } \\
\text { teacher standards. }\end{array}$ \\
\hline
\end{tabular}

Coventry Major changes to the professional development program were made to support improved instruction, but this was done before the knowledge and skill-based pay program was developed. Several courses have been developed to address procedural aspects of the knowledge and skillbased pay system, but otherwise there does not appear to be much explicit linkage between professional development and the pay program.

Douglas County Courses for skill blocks are provided by the district. Although the district offers a substantial number of other professional development classes, none are directly linked to the outstanding teacher program. Completing the portfolio itself was considered a form of professional development.

Limon

Manitowoc

Robbinsdale

The overall professional development program was expanded at the same time the new pay program was developed. The nature of the individual professional growth goals left the choice of development activities to the teacher and supervisor, subject to general district guidelines.
The knowledge and skill-based pay program was directly linked to a specified university professional development program and to locally-developed and provided courses. Existing local courses covered instruction, technology, and student writing.

Due to delays in implementing the program, no specific professional development activities linked to the knowledge and skill-based pay program had been developed at the time of our study.

Vaughn
Relationship to Other Human Resource Programs

The knowledge and skill assessment system is the same as used for teacher performance evaluation. At the time of our study there were no links to teacher recruitment and selection.

A modified version of the Framework for Teaching was used for teacher evaluation. This was also provided to job candidates as part of the recruitment process, and some interview questions are based on Framework elements. Though the district regarded the Framework as consistent with the NBPTS standards and the RHODE program, there was no formal link to the knowledge and skill-based pay programs.

Originally a connection with the state's multiple level licensing system was planned, but delays and changes in the state program prevented this development. Teacher evaluation was connected to regular pay progression, but the only explicit link to the knowledge and skill-based pay program was that teachers rated unsatisfactory cannot apply for the outstanding teacher award.

Initial program tied pay to teacher evaluation system; current program no longer has the direct tie. The overall pay-forperformance system was explained to job candidates during recruitment; administrators felt this led to self-screening and higher retention.

No specific links between this program and other human resource programs had yet been developed.

Due to delays in developing the system, connections with other human resource systems had not been developed at the time of our study. Regular teacher evaluations were one element in teacher portfolio documenting knowledge and skill. Initially, the knowledge and skill-based pay program was used as a recruitment tool, but this ceased with the delay in implementation.

The knowledge and skill-based pay assessment standards were also used for teacher evaluation. The pay system was explained to job candidates as part of job interview. Administrators felt this was a recruiting advantage since most newer teachers could earn more at Vaughn than in the surrounding district. 
may make it difficult to identify specific skills and develop a coherent professional development program linked to the pay system. Those programs with tight links had smaller incentives and made less radical changes in the pay schedule. Manitowoc and Douglas County had the tightest links in that parts of their pay program were directly tied to taking specific courses. However, both had not yet developed more than a relatively few courses covering a limited range of skills, and other professional development opportunities were not yet aligned with a comprehensive knowledge and skill model. The strategy of these two districts appeared to be to start small, paying first for attaining a few important skills. Coventry did not appear to link the professional development program to the pay program, perhaps due to the limited scope of the latter. The Limon program, and Douglas County's outstanding teacher award, gave teachers considerable choice as to what skills would be rewarded and therefore did not provide the basis for a comprehensive, linked professional development program.

At the point at which we studied these programs, the pay systems were not closely integrated with other human resource management activities. Two of the programs with the largest incentives, Cincinnati and Vaughn, combined knowledge and skill assessment with teacher evaluation. Robbinsdale integrated the evaluation system by using it as one of eight elements in its assessment system. Vaughn used the knowledge and skill pay system in recruiting teachers, and Robbinsdale had planned to, but since the system was insufficiently developed, had not done so at the time of our study.
None of the organizations appear to have used the knowledge and skill model in selecting teacher candidates at the time we studied them.

\section{Additional Costs of the Programs and Methods of Funding}

Table 7 shows the estimated additional costs, where available, of the knowledge and skill-based pay programs, and the method of funding these costs. It should be noted that the extra cost of salaries was hard to estimate since there was little experience at most sites to tell how many teachers will move to the higher pay levels, and at what rate they will move. Therefore few solid costs estimates are shown. From the limited data provided, it appears that transition costs can be quite low as can the costs in the first years before many teachers have had a chance to develop the full range of knowledge and skills. However, it is also clear that some of the programs provided the potential of substantially higher salaries. Comparing the maximum pay attainable under the former system with that attainable under the knowledge and skill-based pay system, a teacher in Cincinnati at the top of the schedule has the potential to achieve a $21 \%$ higher pay rate. In Manitowoc, such a teacher has the potential to earn $38 \%$ more, and Vaughn, 22\% more. The other programs provided a substantially smaller additional pay opportunity. Limon provided only about $1.5 \%$ more pay, Coventry, about $11 \%$, and Douglas County, about $7.4 \%$. Robbinsdale's proposed plan provided for the same maximum as in the old schedule.

In none of these cases had estimates of additional administrative costs been made. The assumption appeared to be that the time and staff needed to 
Table 7. Costs and Funding

\begin{tabular}{|c|c|c|}
\hline Site & Costs of Pay and Administration & $\begin{array}{l}\text { Source of Funds for Pay and } \\
\text { Administration }\end{array}$ \\
\hline Cincinnati & $\begin{array}{l}\text { Transition cost to new pay schedule } \\
\text { estimated at } 0.2-0.4 \% \text { of payroll; ultimate } \\
\text { extra cost of pay changes not estimated. Cost } \\
\text { of administration not known, but } \\
\text { compensation for eight full-time teachers to } \\
\text { do classroom observations could be about } \\
\$ 500,000 \text { annually. }\end{array}$ & $\begin{array}{l}\text { Reallocation of some of the dollars spent on } \\
\text { degrees and credits in the current pay schedule, } \\
\text { reallocation of staff time and budget resources to } \\
\text { administer the system. Some new money raised via } \\
\text { higher local taxes. }\end{array}$ \\
\hline Coventry & $\begin{array}{l}\text { Estimate not available because program had } \\
\text { just begun. }\end{array}$ & $\begin{array}{l}\text { Most funding appeared to have come from } \\
\text { increases in state funding. Reallocation of existing } \\
\text { time and funds used to cover administration, most } \\
\text { notably conversion of an administrator position to } \\
\text { Director of Professional Development. }\end{array}$ \\
\hline Douglas County & $\begin{array}{l}\text { District estimate of cost of additional } \\
\text { knowledge and skill pay elements was about } \\
0.5 \% \text { of payroll. No estimate of administrative } \\
\text { costs is available. }\end{array}$ & Additional funds raised from local tax base. \\
\hline Limon & $\begin{array}{l}\text { District has not made an estimate, but if all } \\
\text { teachers received the professional growth } \\
\text { bonus, the cost would be about } 1.4 \% \text { of } \\
\text { payroll. }\end{array}$ & $\begin{array}{l}\text { Reallocation of existing funds and additional funds } \\
\text { raised from local tax base. }\end{array}$ \\
\hline Manitowoc & $\begin{array}{l}\text { No estimate of additional salary costs solely } \\
\text { due to knowledge and skill elements was } \\
\text { available. Total package increase estimated } \\
\text { at } 1.5 \% \text { to } 2 \% \text { of operating budget, and } 3.8 \% \\
\text { of payroll. No additional administrative costs } \\
\text { expected by district. }\end{array}$ & $\begin{array}{l}\text { Local Academy was expected to be self-financing. } \\
\text { New money available from tax base within legal } \\
\text { limits used to finance pay costs. }\end{array}$ \\
\hline Robbinsdale & $\begin{array}{l}\text { No estimate available from district. Since the } \\
\text { program would be applied initially to new } \\
\text { teachers, immediate additional costs would } \\
\text { likely be quite low. }\end{array}$ & $\begin{array}{l}\text { Plan was to reallocate existing funds to cover } \\
\text { additional pay costs. }\end{array}$ \\
\hline Vaughn & $\begin{array}{l}\text { Total performance plan cost about } 3.5 \% \text { of } \\
\text { payroll in 1999-2000, expected to rise to } 6 \% \\
\text { in } 2000-2001 . \text { No estimate of administrative } \\
\text { costs available, but some of the time of three } \\
\text { new administrative positions should be } \\
\text { considered part of the administrative cost. }\end{array}$ & $\begin{array}{l}\text { Reallocation of savings from efficiencies in } \\
\text { management and in managing funds provided by } \\
\text { formula from the state and district; also, new money } \\
\text { provided in the state funding formula was allocated } \\
\text { to pay. }\end{array}$ \\
\hline
\end{tabular}

administer the programs could be added to existing workloads or handled by reallocations of current staff. For several of the programs, this assumption will probably not prove problematic, because of limited scope or reliance on external assessments. For example, because it relied on discrete course grades and external certifications, the Manitowoc system requires little in the way of new administrative machinery, beyond record-keeping. The Limon, Douglas County, and Coventry systems required additional administrator time to review portfolios, but Douglas County, as described by Hall and Caffarella (1997), had not found this a major strain, perhaps because a relatively limited proportion of teachers participated in that part of the program. On the other hand, Cincinnati's experience, in a field test of the assessment system, suggested that most administrators did not have 
the time to do extensive evaluation

(Milanowski \& Kellor, 2000a). In response, the district decided to hire eight teachers to specialize as evaluators. Vaughn, too, had initial difficulties finding the time for peers and administrators to do the required number of classroom observations. The school responded by reallocating positions to provide for more administrators, by increasing use of substitutes to free up the time of peer assessors, and by hiring two retired teachers as part-time assessors. As a charter school, Vaughn had a considerable amount of budgetary flexibility, and was able to tap grant funds to pay for part of these additional administrative costs. These experiences suggest that it is likely that knowledge and skill-based pay designs that use extensive internal assessment will require the allocation of additional resources to program administration.

\section{Discussion}

This report has attempted to summarize some of the main features of seven innovative teacher compensation programs that rewarded teachers for developing their knowledge and skills. Based on a simple theory of action, a model of motivation, and descriptions of private sector experience, a set of dimensions was developed to guide the analysis and comparison of the design of the programs. The major findings from the comparison are summarized below.

Motivation for change. There are a variety of reasons for designing knowledge and skill-based pay programs. Contrary to the assumptions underlying our theory of action, most programs were not primarily motivated by a desire to improve the knowledge and skills of the existing teacher workforce in order to improve student achievement, though some programs were motivated by a desire to recruit and retain more highly-skilled teachers and to support a particular vision of instruction. Other reasons illustrated in these cases were to respond to public pressure for a linkage of teacher pay to performance and to differentiate teacher pay based on teacher quality. State-level student assessment and accountability programs were an important factor in only those cases where student achievement was low. In most of the cases, however, student achievement was not considered a problem. Districts with high or acceptable student achievement appear just as likely to innovate, though the most comprehensive of the programs we studied were found where there was pressure to improve student achievement. Programs in Cincinnati, Coventry, and Vaughn seemed designed to motivate teachers to practice in certain ways, rather than to motivate them to develop specific skills. These programs more closely resemble private sector competency-based pay programs, which often include a more general performance component, while the skill blocks in Douglas County and the Manitowoc program resemble the skill-based pay model in which the development of specified skills is rewarded.

Design process. In all cases, teachers participated in the design of the programs. The larger districts used formal committee structures outside of the collective bargaining process to involve relatively large numbers of teachers in developing the details. The smaller organizations were more likely to have designed their systems with less involvement. Contrary to expectations, 
some programs were designed within the negotiation process, though these tended to be the simpler ones. In all of our cases, a relatively high level of association-management cooperation, or trust between administrators and teachers, was present. Teacher compensation change is possible in a collective bargaining environment, and association or union leaders have been champions of the process.

Knowledge and skills rewarded. The knowledge and skills rewarded are generally those related to instruction, though none of the programs studied placed heavy emphasis on contentspecific pedagogy. At the time we studied the programs, relatively few had defined an integrated model of the knowledge and skills needed for quality instruction, nor a progression of levels of skill development providing a path to mastery, though some of the organizations may have been moving incrementally toward such a model. There was no dominant method of knowledge and skill identification in these cases. Though most of the programs included the National Board standards as part of their model, the Board's standards were typically not highly integrated with the other knowledge and skills rewarded.

Knowledge and skill assessment. All of the programs use some form of performance assessment to review the acquisition of at least some of the knowledge and skills rewarded, rather than relying completely on degrees or credits as indicators of teacher knowledge and skill. Five of the seven programs included external assessments, typically the NBPTS assessments. However, these assessments were not typically integrated into the assessment system as a check on internal assessments, or used as an indicator of a higher level of core teaching skills.

Size and structure of knowledge and skill incentives. As expected, there was some tendency for programs that were motivated by the need to improve student achievement to move farthest from the traditional schedule. These programs were likely to send the strongest motivational signals to teachers. However, in none of these cases were seniority and graduate degrees eliminated as a basis for pay progression. In four of the seven cases, movement away from the traditional salary concepts was incremental.

\section{Support for knowledge and skill} development. Few of the programs we studied have developed a coordinated professional development program that is specifically linked to the knowledge and skill model. Lack of alignment of professional development programs with the knowledge and skill model may reduce the motivational force of the rewards if teachers do not perceive they have the opportunities to acquire the knowledge and skills. That direct links to professional development programs are not strong may be due to the fact that the programs were not intended to remedy knowledge and skill deficits on the part of current staff. None of the programs have fully aligned their human resource management programs with a developmentally-sequenced knowledge and skill model. This suggests that the promise of alignment in fostering a shared conception of good teaching has not yet been fulfilled.

Costs and funding. The cost of transition to a knowledge and skillbased pay system appeared to be low in the short run, though costs are likely to 
increase over time to the point that new money will be needed to fund them. Little information on administrative costs was available, and in most of the cases, the increased administrative costs were met using existing resources. For the more ambitious programs, administrative costs are likely to be significant, and may not have been fully realized at the time of our study.

\section{Implications for Research on Knowledge and Skill-based Pay in the K-12 Sector}

Unlike the private sector where skillbased pay and competency-based pay systems appear to have become relatively codified, there are multiple models of knowledge and skill-based pay in the $\mathrm{K}-12$ sector. These various models were designed to serve a variety of purposes, not simply to support improved instruction. This implies that in evaluating the success of knowledge and skill-based pay programs, it will be important to take into account other program goals and to develop measures of program impact in addition to measures of instructional capacity or student achievement. For example, to the extent that recruitment and retention of highly-skilled teachers is an important goal, the quality of new hires and the degree to which more-skilled teachers are retained and less-skilled teachers leave will be an important outcome to measure. To the extent that programs are a response to community pressure for pay-for-performance or accountability, it may be necessary to look at community perceptions of the program. One rough indicator that Douglas County and Cincinnati informants mentioned was increased willingness on the part of the community to pass referenda providing more tax money for education. To the extent that the goal is to support the diffusion of a particular vision of teaching, measuring teacher acceptance and implementation of this vision will be important.

Of course, the most important outcome to many organizations considering developing and funding knowledge and skill-based pay programs is likely to be whether they are effective in motivating skill acquisition, changing instruction, and improving student achievement. But because knowledge and skill-based pay at this point encompasses such a variety of designs, it will be important to develop some measures of the potential causal "strength" of the program. A set of benchmarks could be developed as was done by evaluators of the New American Schools implementation in Memphis (Smith et al., 1998; Ross, 2000). This would entail using the theory of action and motivational model to specify dimensions and develop some rubrics for judging how close the design and implementation come to the ideal specified in the theory, then relating these ratings to measures of effects. For example, the theory of action and motivational model suggest that a program providing few professional development opportunities, little administrator and peer support for new skill acquisition, and relatively small incentives, would have a limited effect on instruction and student achievement. In such a case, lack of evidence that knowledge and skill-based pay was associated with improved instruction or student achievement would not be surprising, but also would not provide much information about whether a stronger knowledge and skill-based pay design can help improve instruction. 
It is interesting to speculate as to whether knowledge and skill-based pay in the K-12 sector will evolve toward a plurality of systems reflecting strategic district or school goals, local history, and designers' preferences, or toward a family of similar systems based on external, generic standards. In the private sector, the theoretical argument for knowledge and skill-based pay is that it can provide incentives to develop organization-specific skills that support a unique competitive strategy. The K-12 analog would be a set of schools operating under school choice or voucher systems, with little procedural regulation. Of our cases, the Vaughn charter school best fits this model and it did "tailor" its knowledge and skill model more closely to its mission as set forth in its charter. But as argued above, in the $\mathrm{K}-12$ sector the core skills are likely to be similar across schools and districts, and there is little competition across schools or districts. Thus, over time we may see a tendency for convergence on external standards and assessments. The limiting factor appears to be a lack of external assessments aimed at differentiating among midcareer teachers.

\section{Implications for Policymakers and Program Designers}

The experiences of the seven organizations we studied suggest a number of fairly clear lessons for the design of knowledge and skill-based pay programs. First, that even the most radical of the seven programs we studied retained seniority and degrees as pay criteria suggests that it may be unrealistic to expect completely performance-based pay systems to emerge. It may be necessary to retain some aspects of the traditional structure in order to have a realistic chance of implementing a pay system that rewards the acquisition of instructionrelevant knowledge and skills. As the Cincinnati and Vaughn cases illustrate, a program can be designed to provide significant incentives for knowledge and skill development while retaining some rewards for seniority.

Second, teachers' associations may be more open to changes in pay systems than administrators or school board members expect, but this openness is likely to be the product of high levels of trust developed through cooperation on other issues, and design features aimed at encouraging acceptance by senior teachers may be needed.

Third, it may be easier and faster to adapt a set of pre-existing teacher standards rather than to develop a knowledge and skill model from scratch.

Fourth, the transition costs to even a fairly extensive knowledge and skillbased pay structure can be low. It is, however, likely that administrative costs will be higher where an extensive system of internal skill assessment is used, and that payroll costs may significantly increase in the long term. So it is advisable to plan for ways to cover these costs.

It is also interesting to note that, for these pioneer organizations, state programs such as assessment and accountability systems or teacher licensing supported rather than drove teacher compensation change. Local issues, union-management relations, and the agendas of leaders were probably more important as initiators of change, and will likely be very important in sustaining and guiding a program until it has taken hold. For 
state-level policymakers who desire to use salary dollars more strategically to improve student achievement, one implication is that it may be useful to provide a comprehensive and coherent model of knowledge and skills that are directly related to improving instruction for local organizations to adapt and customize. This would help focus teacher compensation change on strategically-important goals. The model could also be linked to state standards for students. If one way to improve student achievement toward state content standards is to ensure that teachers can develop and teach highquality standards-based curriculum units to all students (Cohen \& Hill, 2000), then the model should emphasize the knowledge and skills needed to do this. Integration of the model with a multi-level licensing system and providing funds to increase pay for teachers with higher-level licenses could be another way for state-level policymakers to focus the system on strategically important goals.

Not only might state-level action help to encourage greater coherence and focus on improved instruction, but there may also be significant efficiencies to be gained from developing a state-level model rather than having each district or school work on the problem alone. External assessments could be developed for common knowledge and skill elements to lower the burden on local schools and districts. One state that has been working along these lines is Iowa, where state, education, business, and political leaders developed a comprehensive model for teacher performance evaluation, licensing, and compensation (Iowa Department of Education, 2000). Yet the ability of local organizations to customize a state model should be retained in order to maximize the potential for local acceptance and to recognize that, at this early stage, no one knowledge and skillbased pay model has emerged as "best practice." 


\section{References}

American Compensation Association. (1996). Raising the bar: Using competencies to enhance employee performance.

Scottsdale, AZ: Author.

Bembry, K. L., Jordan, H. R., Gomez, E., Anderson, M. C., \& Mendro, R. L. (1998, April). Policy implications of long-term teacher effects on student achievement. Paper presented at the annual meeting of the American Educational Research Association, San Diego, CA.

Cohen, D. K., \& Hill, H. (2000). Instructional policy and classroom performance: The mathematics reform in California. Teachers College Record, 102(2), 294-343.

Conley, S. C., \& Odden, A. R. (1995). Linking teacher compensation to teacher career development. Educational Evaluation and Policy Analysis, 17(2), 219237.

Daniels, D. R. (1997). Competency-based compensation approaches. In P. T. Chingos (Ed.), Paying for performance: $A$ guide to compensation management (pp. 72-95). New York: Wiley.

Danielson, C. (1996). Enhancing professional practice: A framework for teaching. Alexandria, VA: Association for Supervision and Curriculum Development.

Dwyer, C. A. (1998). Psychometrics of PRAXIS III: Classroom performance assessments. Journal of Personnel Evaluation in Education, 12(2), 163-187.

Ferguson, R., \& Ladd, H. (1996). How and why money matters: An analysis of Alabama schools. In H. Ladd (Ed.), Holding schools accountable: Performance- based reform in education (pp. 265-298). Washington, DC: Brookings Institution.

Fisher, R., \& Ury, W. (1981). Getting to yes. Boston: Houghton-Mifflin.

Gorsline, K. (1996). A competency profile for human resources: No more shoemaker's children. Human Resource Management, 35(1), 53-66.

Gupta, N., Jenkins, G. D., \& Curington, W. P. (1986). Paying for knowledge: Myths and realities. National Productivity Review, 5(2), 107-123.

Hall, G. E., \& Caffarella, E. P. (1997). Third-year implementation assessment of the Douglas County, Colorado school district performance pay plan for teachers. No city: Authors.

Heneman R. L., \& Ledford, G. E. (1998). Competency pay for professionals and managers in business: A review and implications for teachers. Journal of Personnel Evaluation in Education, 12(2), 103-122.

Heneman, R. L., \& Thomas, A. L. (1997). Using strategic performance management to drive brand leadership. Compensation and Benefits Review, 27(6), 33-40.

Interstate New Teacher Assessment and Support Consortium. (1992). Model standards for beginning teacher licensing and development: A resource for state dialog. Washington, DC: Author.

Iowa Department of Education. (2000). A proposal for a new teacher compensation system based on teacher performance, career development, and the national labor market. Des Moines, IA: Author. 
Jaeger, R. J. (1998). Evaluating the psychometric qualities of the National Board for Professional Teaching Standards' assessments: A methodological accounting. Journal of Personnel Evaluation in Education, 12(2), 189-210.

Jenkins, G. D., Ledford, G. E., Gupta, N., \& Doty, D. H. (1992). Skill-based pay: Practices, payoffs, pitfalls, and prescriptions. Scottsdale, AZ: American Compensation Association.

Jones, T. W. (1995). Performance management in a changing context: Monsanto pioneers a competency-based developmental approach. Human Resource Management, 34(3), 425-442.

Lawler, E. E. III (2000). Rewarding excellence: Pay strategies for the new economy. San Francisco: Jossey-Bass.

Ledford, G. E. (1991). The design of skill-based pay plans. In M. L. Rock \& L. A. Berger (Eds.), The compensation handbook ( $3^{\text {rd }}$ edition, pp. 199-217). New York: McGraw Hill.

Ledford, G. E., \& Heneman, R. L. (2000). Pay for skills, knowledge, and competencies. In L. A. Berger \& M. L. Rock (Eds.), The compensation handbook ( $4^{\text {th }}$ edition). New York: McGraw-Hill.

Milanowski, A. T., \& Kellor, E. (1999). Vaughn Next Century Learning Center performance pay survey: Preliminary report. Unpublished manuscript, University of Wisconsin-Madison.

Milanowski, A. T., \& Kellor, E. (2000a). Teacher and evaluator reactions to standards-based teacher evaluation in the Cincinnati Public Schools: An evaluation of the 1999-2000 field test of the new evaluation system. Unpublished manuscript, University of WisconsinMadison.

Milanowski, A. T., \& Kellor, E. (2000b). Vaughn Next Century Learning Center performance pay survey: School report. Unpublished manuscript, University of Wisconsin-Madison.

Milanowski, A. T., Odden, A. R., \& Youngs, P. (1998). Teacher knowledge and skill assessment and teacher compensation: An overview of measurement and linkage issues. Journal of Personnel Evaluation in Education, 12(2), 83-101.

Mohrman, A., Mohrman, S. A., \& Odden, A. R. (1996). Aligning teacher compensation with systemic school reform: Skill-based pay and groupbased performance rewards. Educational Evaluation and Policy Analysis, 18(1), 5171.

National Board for Professional Teaching Standards. (1999). What teachers should know and be able to do. Arlington, VA: Author.

National Board for Professional Teaching Standards. (2001). State incentives. Retrieved from http:/ / www.nbpts.org/news/-center/ facts/state_incentives.html.

National Commission on Teaching and America's Future. (1996). What matters most: Teaching for America's future. New York: Author.

Odden, A. R. (2000). New and better forms of teacher compensation are possible. Phi Delta Kappan, 81(5), 361366.

Odden, A. R., \& Kelley, C. (1997). Paying teachers for what they know and do: New 
and smarter compensation strategies to improve schools. Thousand Oaks, CA: Corwin Press.

Ross, S. M. (2000). How to evaluate comprehensive school reform models. Getting Better by Design, Series 8 (pp. 114). Arlington, VA: New American Schools Development Corporation.

Shippmann, J. S., Ash, R. A., Battista, M., Carr, L., Eyde, L. D., Hesketh, B., Kehoe, J., Pearlman, K., Prien, E. P., \& Sanchez, J. I. (2000). The practice of competency modeling. Personnel Psychology, 53(3), 703-740.

Shulman, L. S. (1987). Knowledge and teaching: Foundations of the new reform. Harvard Educational Review, 57(1), 1-22.

Slavin, R., \& Fashola, O. (1998). Show me the evidence! Proven and promising programs for America's schools. Thousand Oaks, CA: Corwin Press.

Smith, L., Ross, S., McNelis, M., Squires, M., Wasson, R., Maxwell, S., Weddle, K., Nath, L., Grehan, A., \& Buggey, T. (1998). The Memphis restructuring initiative: Analysis of activities and outcomes that affect implementation success. Education and Urban Society, 30(3), 296-325.

Spencer, L. M., \& Spencer, S. M. (1993). Competence at work: Models for superior performance. New York: Wiley.

Tucker, S. A., \& Cofsky, K. M. (1994). Competency-based pay on a banding platform. ACA Journal, 3(1), 30-45.

Vroom, V. H. (1964). Work and motivation. New York: Wiley.
Wise, A. E., Darling-Hammond, L., McLaughlin, M. W., \& Bernstein, H. T. (1984). Teacher evaluation: A study of effective practices. Santa Monica, CA: RAND Corporation.

Wright, S. P., Horn, S. P., \& Sanders, W. L. (1997). Teacher and classroom context effects on student achievement: Implications for teacher evaluation. Journal of Personnel Evaluation in Education, 11(1), 57-67.

Zingheim, P. K., Ledford, G. E., \& Schuster, J. R. (1996). Competencies and competency models: Does one size fit all? American Compensation Association Journal, 5(1), 56-65. 


\section{Appendix A. Brief \\ Descriptions of the Seven Knowledge and Skill- based Pay (KSBP) Case Sites}

\section{Cincinnati}

The Cincinnati public school district is the state of Ohio's third largest, enrolling about 48,000 students in 78 schools. The student population is $71 \%$ African American, the rest White or other. About $65 \%$ are eligible for free or reduced-price lunch. A relatively large proportion of Cincinnati's school-age children attend private schools, which, given the state's school funding system and laws requiring referenda for increases in school spending, has faced the district with pressures to reduce costs and improve student achievement. Average per-pupil spending was about $\$ 8,000$ in 1998-1999. The average teacher base salary was about $\$ 44,000$. Fifty-one percent of the district's 3,000 teachers have Master's degrees and the average level of teaching experience is 15 years. The district has a seven-person elected school board on which the members serve staggered four-year terms. Teachers are represented by a local affiliate of the American Federation of Teachers. Cincinnati began developing its knowledge and skill-based pay program in 1996 with a commitment to redesign the teacher evaluation system. The new evaluation system, which will be the foundation for the KSBP program, was field-tested in the 19992000 school year and will be used in the 2001-2002 and 2002-2003 school years before the pay component. The pay component has been fully designed and was included in the collective bargaining agreement approved by the board and the local Federation of Teachers in the spring of 2000. In 20032004 , the pay component will be added unless a super-majority of teachers vote to reject the program in May 2003. In addition to the knowledge and skillbased pay structure, a group bonus of $\$ 1,400$ is to be paid to all teachers in schools that meet schoolwide goals for improving student achievement.

\section{Coventry}

The Coventry, Rhode Island district is one of the fastest growing suburban districts in the Northeast. It serves 5,600 students in nine schools. The student population is $98 \%$ White and $2 \%$ minority. About $22 \%$ are eligible for free or reduced-price lunch. Student population has been growing moderately. Average per-pupil spending was $\$ 7,400$ in 1997-1998, and the average teacher base salary was about $\$ 50,000$. About $80 \%$ of the district's 351 teachers have Master's degrees and the distribution of teaching experience is bimodal, with about $60 \%$ very long service and $40 \%$ five or fewer years. Teachers are represented by a local affiliate of the American

Federation of Teachers. Coventry began developing its new pay system in 1995, when the association proposed recognition of National Board certification. The initial element of the program, a bonus for National Board certification, was implemented in 1996. Additional pay for knowledge and skill elements were implemented for the 2000-2001 school year.

\section{Douglas County}

The Douglas County, Colorado school district, located in a fast-growing area between Denver and Colorado 
Springs, enrolls more than 32,000 students in 49 schools. (Thirty-two schools were opened since 1989.) The student population is $91 \%$ White, $4 \%$ Hispanic, and $5 \%$ other. About $2 \%$ are eligible for free or reduced-price lunch. Average per-pupil spending was $\$ 7,817$ in 1996-1997, and the average teacher base salary about $\$ 39,680$ in 1998 . The average level of teaching experience is approximately eight years. Teachers are represented by a local affiliate of the American Federation of Teachers. The process of developing the new pay system began in the 1991-1992 school year, but the major design activities took place from July 1993 to the beginning of the 1994-1995 school year. The current plan was first implemented during the 1994-1995 school year and has continued with minor modification since. Besides knowledge and skill elements, it also includes a modification of the traditional pay schedule that makes seniority pay progression dependent on satisfactory performance evaluation, a school group bonus program, and added pay for additional school- or district-level responsibilities.

\section{Limon}

The Limon, Colorado school district serves 660 students in two schools. Located in a rural area, the district's students are $91 \%$ White, $5.6 \%$ Hispanic, and $3.4 \%$ other. About $34 \%$ are eligible for free or reduced-price lunch. The size of the student population is now stable after a brief period of increase in the early 1990s. Average per-pupil spending was $\$ 5,643$ in 1996-1997, and the average teacher base salary was $\$ 27,900$ in 1998. Twenty percent of the 44 teachers have Master's degrees, and the average level of teaching experience is about 10 years. Teachers are represented by a local association affiliated with the
National Education Association, but only a minority of teachers pay state and local dues, and collective bargaining is essentially informal with no formal contract negotiated. Pay innovation began in 1994-1995 with the development of a link between pay increases and teacher performance evaluations. The traditional step and lane schedule was eliminated in favor of merit pay, which was based on principal evaluation in accordance with the state evaluation standards. The current plan was introduced for the 1998-1999 school year. In addition to knowledge and skill-based pay, the pay system also has the potential for a $\$ 400$ increase if building-level goals are met and a $\$ 400$ increase for achieving unit - or gradelevel goals.

\section{Manitowoc}

The Manitowoc, Wisconsin school district is located in a community of 33,000 in the eastern part of the state. It serves almost 6,000 students in five schools. The student population is $86 \%$ White and $14 \%$ minority. Student population growth has leveled off and is expected to decline. About $1 \%$ are eligible for free or reduced-price lunch. Average per-pupil spending is about $\$ 7,692$, and the average teacher base salary is about $\$ 37,240$. Relatively few of the district's 420 teachers have Master's degrees, but the average level of teaching experience is relatively high. Teachers are represented by a local affiliate of the National Education Association. Manitowoc began developing the new pay system in early 1999 as part of negotiations for the 19992001 teachers' contract. The system went into effect for the 2000-2001 school year. 


\section{Robbinsdale}

The Robbinsdale, Minnesota school district is located in a suburban area outside Minneapolis-Saint Paul. It serves approximately 14,000 students, of whom $20 \%$ are non-White and $22 \%$ are eligible for free or reduced-price lunch. (It should be noted, however, that within the district, the percentage eligible for free or reduced-price lunch varies widely by school, from $15 \%$ to $80 \%$.) The student population is slowly increasing. Average per-pupil spending is about $\$ 8,555$, and the average teacher base salary is about $\$ 44,950$. Forty-eight percent of the 900 teachers have Master's degrees and the average level of teaching experience is 14 years. Teachers are represented by a local affiliate of the American Federation of Teachers. The process of developing a new pay system began in 1994. Through the negotiation process, an outline of a plan was developed as part of the 19951997 collective bargaining agreement, but the tentative contract was rejected by the membership. A revised program structure was approved as part of the 1997-2000 contract. The district is still working to develop the components, and the program has not yet gone into effect.

\section{Vaughn}

Vaughn Next Century Learning Center is a public charter school in San Fernando, California. Previously a public school in the Los Angeles Unified School District, the school converted to charter status in July 1993. It currently serves about 1,200 students in pre-K through grade 5 . The student population is $94 \%$ Hispanic, $5.5 \%$ African American, and .5\% other. Only $13 \%$ of the students are considered to be English proficient. About $98 \%$ are eligible for free or reduced-price lunch. The average teacher base salary was $\$ 42,000$ in 1999-2000. The average level of teaching experience is seven years. Vaughn is governed by three staff/parent committees, with a special council existing to oversee and resolve disputes between the three committees. Teachers as a group are not represented at this time, though some individual teachers are members of the American Federation of Teachers or National Education Association. The school began developing its KSBP program during the 1997-1998 school year. An initial implementation for new teachers and volunteers was done in the 19981999 school year. During that year, 19 of the $50+$ teachers participated in the program. An improved version was put into place, again for new teachers and volunteers, for the 1999-2000 school year, during which 37 classroom teachers participated. The program was continued during the 2000-2001 school year. Vaughn's knowledge and skillbased pay is part of a complete redesign of the pay system that also included pay for additional duties and a group bonus of $\$ 1,500$ for all teachers if the school meets the student achievement goals in the charter. In addition, the school is eligible for a state program that provides bonuses to teachers in schools that meet state-set goals for improving student achievement. 